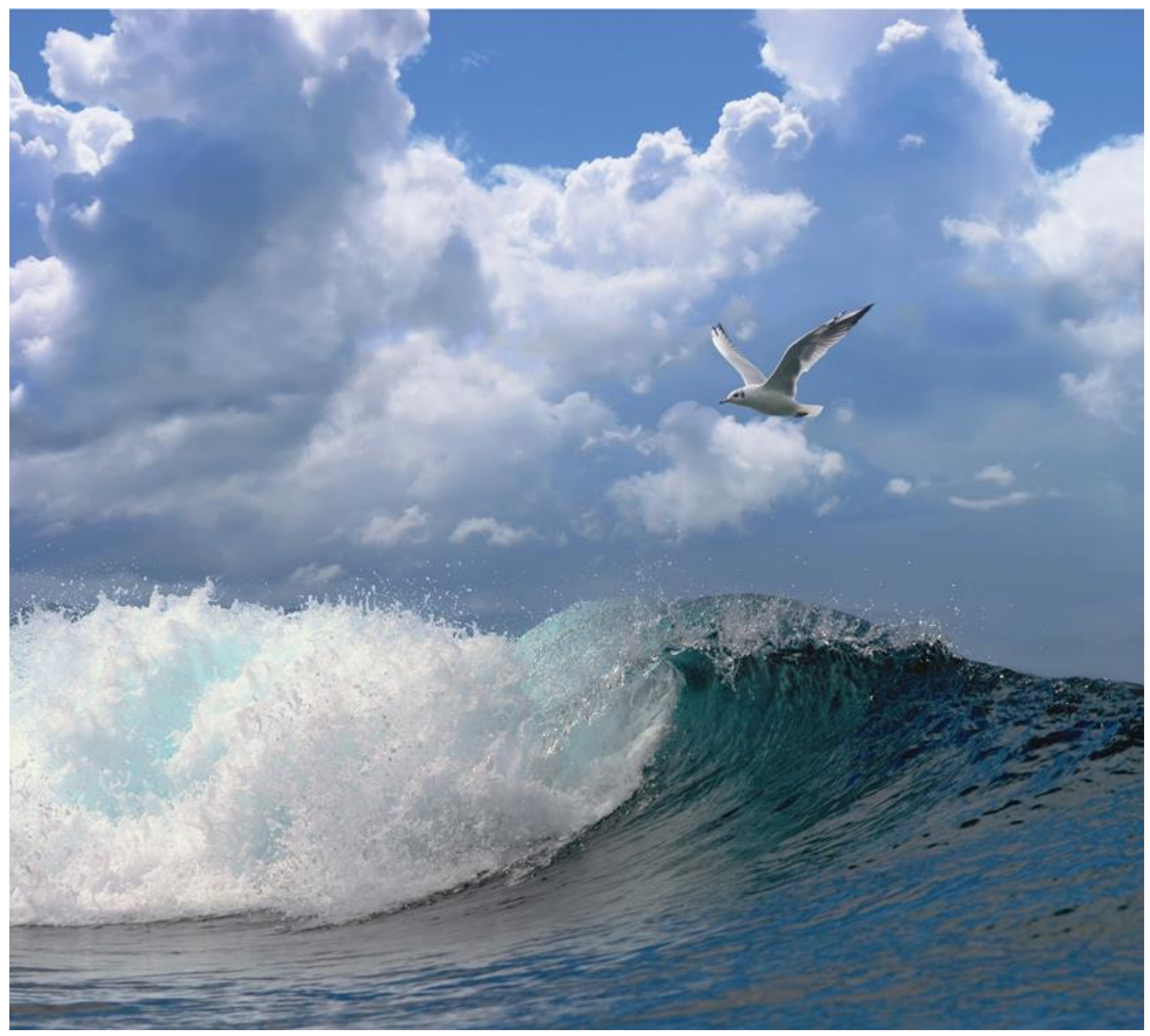

Development of benthos and birds in an intertidal area created for coastal defence (Scheldt estuary, the Netherlands) 


\section{Development of benthos and birds in an intertidal area created for coastal defence (Scheldt estuary, the Netherlands)}

Ysebaert ${ }^{1,2}$

${ }^{1}$ Wageningen Marine Research, ${ }^{2} \mathrm{NIOZ}$ 
Keywords: managed realignment, benthic macroinfauna, birds, intertidal habitat, colonization.

Client:

HZ University of Applied Science

Attn.: Dr. Ing. Joost Stronkhorst

Edisonweg 4

$4382 \mathrm{NW}$, Vlissingen

This report can be downloaded for free from https://doi.org/10.18174/475792

Wageningen Marine Research provides no printed copies of reports

Wageningen Marine Research is ISO 9001:2015 certified.

Photo cover: Edwin Paree

(C) Wageningen Marine Research

Wageningen Marine Research, an institute Wageningen Marine Research accepts no liability for consequential damage, nor within the legal entity Stichting for damage resulting from applications of the results of work or other data Wageningen Research (a foundation under obtained from Wageningen Marine Research. Client indemnifies Wageningen Dutch private law) represented by $\mathrm{Dr}$. Marine Research from claims of third parties in connection with this application. M.C.Th. Scholten, Managing Director All rights reserved. No part of this publication may be reproduced and / or published, photocopied or used in any other way without the written permission

KvK nr. 09098104, of the publisher or author.

WMR BTW nr. NL 8113.83.696.B16.

Code BIC/SWIFT address: RABONL2U

IBAN code: NL 73 RABO 0373599285 


\section{Contents}

Summary

1 Introduction $\quad 5$

2 Methods $\quad 6$

2.1 The study area 6

2.2 Morphological changes $\quad 7$

2.3 Colonization by macrobenthic infauna $\quad 7$

2.4 Comparison of the community structure in the managed realignment area versus natural tidal flats $\quad 7$

2.5 Birds $\quad 8$

2.6 Statistical analysis $\quad 9$

Development of the community structure in Perkpolder 9

Explanatory environmental variables $\quad 9$

Community traits $\quad 9$

$\begin{array}{llr}3 & \text { Results } & 10\end{array}$

3.1 Morphological changes $\quad 10$

Area-wide spatial and temporal morphological changes $\quad 10$

Spatial and temporal morphological changes at the benthic macrofauna sampling stations

3.2 Colonization by macrobenthic infauna 13

$\begin{array}{lll}3.3 & \text { Community structure } & 13\end{array}$

$\begin{array}{lll}3.4 & \text { Environment and traits } & 18\end{array}$

$\begin{array}{lll}3.5 & \text { Birds usage of Perkpolder } & 24\end{array}$

4 Discussion $\quad 27$

$\begin{array}{llr}5 & \text { Conclusion } & 28\end{array}$

$6 \quad$ Quality Assurance $\quad 30$

$\begin{array}{lr}\text { References } & \mathbf{3 0}\end{array}$

$\begin{array}{lr}\text { Justification } & 32\end{array}$ 


\section{Summary}

Landward retreat of coastal defences (managed realignment) will result in the formation of newly flooded habitats exposed to tidal inundation. Creation of intertidal habitats for coastal defence is one of several 'soft' engineering options that could reduce maintenance costs of dikes and at the same time deliver environmental and societal benefits. For future coastal management it is important to understand how newly flooded coastal areas will develop. Will flooded areas develop into productive ecosystems with high ecological and recreational value or remain in an undesirable state for an extended time. Insight in the development of flooded areas may provide decision makers with sufficient knowledge for future implementation of these mitigation measures.

The managed realignment Perkpolder is one of the first in the Dutch part of Scheldt estuary, undertaken as climate adaptation measure. The newly developing intertidal habitat acts as a safety buffer for the surrounding dikes and by means of sedimentation will rise with rising sea-levels. This study assessed initial colonization and development of the benthic macrofaunal community in this newly flooded managed realignment area and the usage of the area by birds.

Initial colonisation of the site by intertidal benthic macroinfauna was rapid with 19 species recorded during the first sampling, four months after the sea defences were breached in June 2015. The pioneering benthic community inside the managed realignment was however structurally different from the estuarine area outside the managed realignment. The mud shrimp Corophium volutator was among the early colonizers. After three years of tidal inundation the benthic community within the realignment site still differs from the community found on the nearby tidal flats, but does develop in this direction.

With the colonization of the benthic macrofauna into the Perkpolder area, also estuarine birds visit the area. Waders like Eurasian curlew (Numenius arquata) and Oystercatcher (Haematopus ostralegus), and the Common shelduck (Tadorna tadorna) are foraging during low tide in the intertidal zone, while the creeks are used by ducks such as Mallard (Anas platyrhynchos) and Wigeon (Mareca penelope). Little egrets (Egretta garzetta) look for small fish and crustaceans in the creeks. No comparison was made with nearby tidal flats, as low water bird counts were not available in the Westerschelde.

The development of the managed realignment Perkpolder is encouraging. A biologically active intertidal area has formed within a short time frame. Within 3 years the benthic macroinfaunal community shows a development towards a community found on natural tidal mudflats and is expected to reach a stable community in years rather than decades. The area is frequently visited by birds which forage during low tide and rest on the surrounding dikes during high tide. 


\section{Introduction}

Intertidal habitats absorb and attenuate wave energy, buffering for flood protection. Under influence of sea level rise intertidal habitats can grow to higher elevations and move inland. Man-made flood defences however prevent inland movement leading to narrowing of these areas, a process known as coastal squeeze. Loss of intertidal habitats combined with rising sea levels results in high maintenance costs of coastal defences and asked for more cost effective and sustainable methods of coastal protection. Managed realignment (setting back defences inland of the original to stimulate rising ground) has become an increasingly common mechanism to compensate for habitat loss and to increase sustainability of flood defences (Esteves, 2014). Landward retreat of coastal defences will result in the formation of newly flooded habitats exposed to tidal inundation. In riverine situations, setting back defences reconnects the river to its flood plain, making room for the river to buffer for increased precipitation reducing flood risks. Creation of intertidal habitats by managed realignment for coastal defence is one of several 'soft' engineering options that could reduce maintenance costs of dikes and at the same time deliver environmental and societal benefits. For future coastal management it is important to understand how newly flooded coastal areas will develop. Will flooded areas develop into productive ecosystems with high ecological and recreational value or remain in an undesirable state for an extended time. Insight in the development of flooded areas may provide decision makers with sufficient knowledge for future implementation of these mitigation measures.

Primary producers like benthic diatoms are the foundation of intertidal flat food webs. They are an important food source for primary consumers like benthic macrofauna such as polychaetes, molluscs and crustaceans. Benthic macrofauna on their turn are a key food source for secondary consumers including fish, crustaceans and birds. As of this, the rate at which the benthic macrofaunal community develops in a newly flooded coastal area is expected to influence total biodiversity and ecosystem functioning.

Previous studies showed initial colonization by bentic macrofauna could occur within days and reach a stable community composition after months or a few years (Moseman et al. 2004; Mazik et al. 2007) but it may also take years to decades (Levin et al. 1996; Craft and Sacco 2003). Colonization and succession depend on local environmental conditions. Characteristics of the sediment is one of the key factor controlling colonization and succession. Garbutt et al. (2006) noted no colonization on agricultural remains whereas rapidly colonization occurred in areas with newly accreted sediments. To understand the development of newly flooded areas, monitoring is necessary as there is no consensus on how newly flooded area are colonized and develop over time.

The managed realignment Perkpolder is one of the first in the Dutch part of Scheldt estuary, undertaken as climate adaptation measure. In the future, other areas will be flooded, such as Hedwige-Prosper. The newly developing intertidal habitat acts as a safety buffer for the surrounding dikes and by means of sedimentation will rise with rising sea-levels. This study assesses initial colonization and development of the benthic macrofaunal community in this newly flooded managed realignment area and the usage of the area by birds. Development of the benthic macrofauna community was compared to the community found in adjacent intertidal areas in the Schelde estuary. Furthermore, the relation between species and community traits and environmental characteristics was investigated. Traits based models were used to examine which traits best explained environmental responses. 


\section{Methods}

\subsection{The study area}

The Scheldt estuary is one of the longest estuaries in NW Europe with a complete salinity gradient. It is a macrotidal system and measures $160 \mathrm{~km}$ from the mouth near Vlissingen (The Netherlands) to Gent (Belgium). The study area is located in the Western Scheldt, which is the Dutch part of the River Scheldt connected to the North Sea (Figure 1). The mean tidal range in the Western Scheldt increases from 3.5 $\mathrm{m}$ from the mouth of the estuary to $5 \mathrm{~m}$ at the Dutch/Belgian border. The mean annual river discharge is $105 \mathrm{~m}^{3} \mathrm{~s}^{-1}$ with low summer discharges $\left(20 \mathrm{~m}^{3} \mathrm{~s}^{-1}\right)$ and high winter discharges $\left(400 \mathrm{~m}^{3} \mathrm{~s}^{-1}\right)$. Depending on the river discharge residence time of the water in the estuary range from 1 to 3 months (Soetaert \& Herman, 1995). The Western Scheldt has a complex morphology with flood and ebb channels and intertidal mud and sand flats. The average depth of the channel is $15-20 \mathrm{~m}$. The Scheldt estuary is an important Nature 2000-area for a large number of birds. Especially the intertidal flats provide essential feeding grounds for waders, with benthic macrofauna as main food source.

A 75 ha intertidal habitat was created at Perkpolder as a managed coastal realignment project, where new dikes were constructed along the inland perimeter and flooding occurred through a single breach in the original dike (Figure 1). Before flooding, the area was used for agriculture. Prior to inundation channels were dug in the realignment site to ensure water retain in the area to enhance ecological development of the area. On $25^{\text {th }}$ of June 2015 a single breach in the sea defences at Perkpolder allowed 75 ha of farmland to be inundated by the sea for the first time in at least 380 years. The inflow of water had a direct impact on erosion and sedimentation processes, which give rise to morphological changes in the area. The resulting intertidal habitat can be classified as low dynamic mid litoral (25-75\% emersion time) located at the poly/mesohaline (average salinity between 10-18) transition zone of the Western Scheldt.

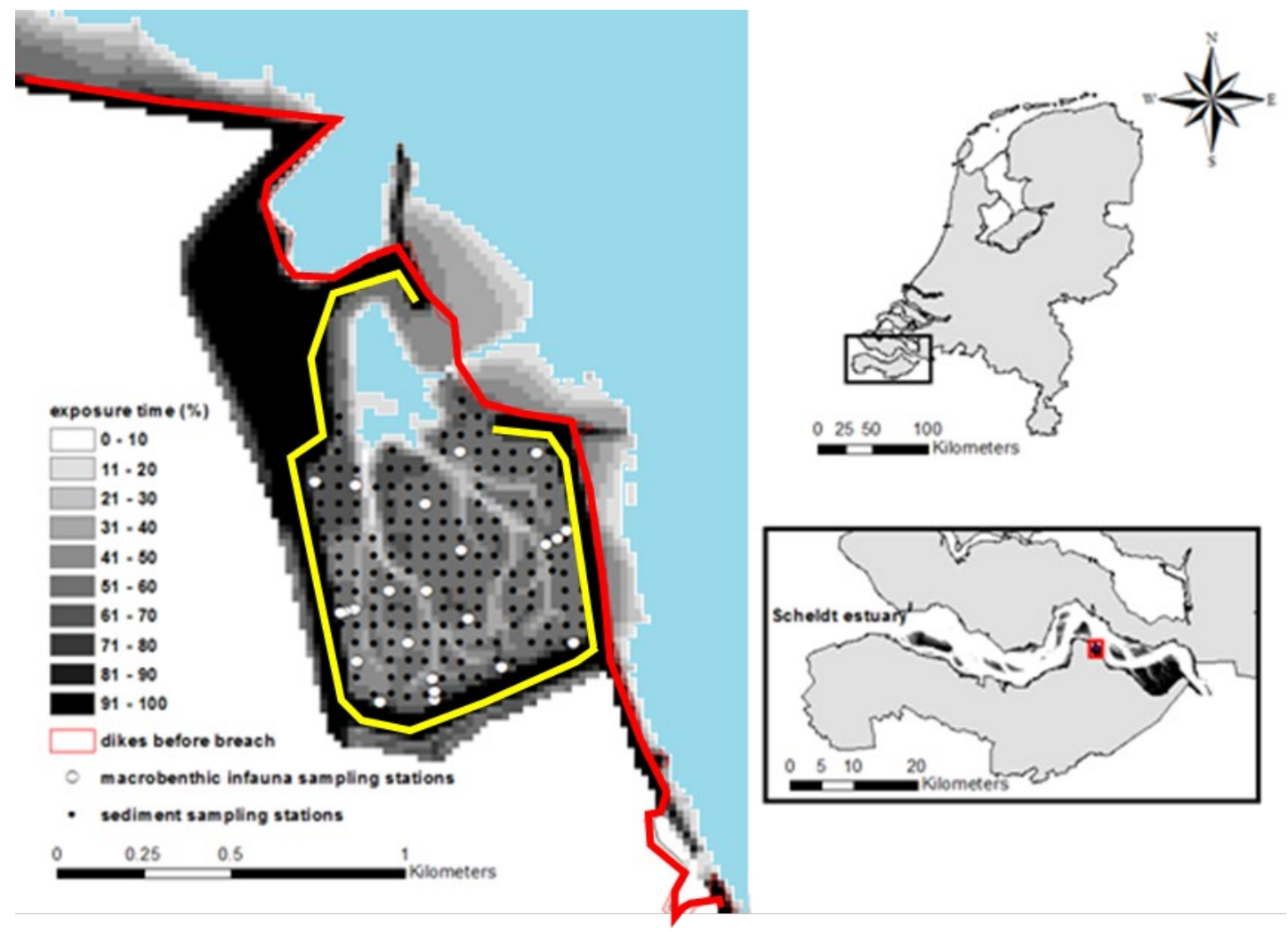

Figure 1. Map of the Perkpolder managed realignment site in the Scheldt estuary (southwest of The Netherlands) with the twenty-four macrobenthic infauna sampling stations and the two-hundred sediment characteristic sampling stations. Red line indicates the original dike, yellow the new dike. 


\subsection{Morphological changes}

To monitor spatial and temporal variation in sediment accumulation and physical properties several sampling campaigns were carried out after inundation of the area. Spatial variation of these parameters was investigated by sampling 200 stations equally spaced throughout the managed realignment in autumn 2016, 2017 and 2018 (Figure 1). Temporal variation was studied by sampling 15 stations in $2015(n=3$ times per year), $2016(n=6), 2017(n=3)$ and $2018(n=4)$.

At each station a single sediment sample $\left(18.5 \mathrm{~cm}^{3}\right.$ ) was collected from the upper $3 \mathrm{~cm}$ (using a 1.4 in diameter syringe from which the tip was cut off) and stored in a pre-weighed sample bottle. Samples were wet weighted and placed in a freezer for a minimum of 3 days before opening the bottles and freeze dry (Christ ${ }^{\circledR}$ Alpha 1-4) the sediment samples for 4 days. Samples were reweighed after freeze drying. Bulk density of the sediment $\left(\mathrm{g} \mathrm{cm}^{-3}\right)$ was calculated as ratio dry weight to the sampled volume. Sediment particle size distribution was determined by laser diffraction (Malvern Mastersizer 2000), from which the median grain size of the sediment $D_{50}(\mu \mathrm{m})$ as well as the size distribution (percentage coarse, medium, fine and very fine sand, and silt) was derived. The average depth of the mud layer $(\mathrm{cm})$ on top of the old farmland was randomly measured $(n=10)$ at each station using a ruler. Elevations (m NAP) were measured using a differential GPS device with a horizontal and vertical measure accuracy of 8 and 13 mm, respectively (Leica GS12, Leica Geosystems AG, Switzerland, correction signal: SmartNet, Leica Geosystems, the Netherlands). Furthermore, average $(n=5)$ sediment penetration resistance $(N)$ and average $(n=5)$ erosion resistance $(\mathrm{KPa})$ of the sediment was measured at each station using a penetrologger and a shear vane, respectively.

\subsection{Colonization by macrobenthic infauna}

To quantify the colonisation of macrobenthic infauna and their community structure twenty-four stations inside the managed realignment site were sampled (Figure 1). Sampling was first undertaken in autumn 2015, four months after the breach. Subsequent sampling took place annually in spring and autumn for three years. In 2015, 2016 and 2017 samples were collected at sixteen, relatively easy accessible stations situated close to the dike. In 2018 the sampling effort was increased with samples covering also the middle part of the managed realignment site. Macrobenthic infauna was sampled using a $10 \mathrm{~cm}$ i.d. corer, i.e. $78 \mathrm{~cm}^{2}$ surface area to a maximum depth of $35 \mathrm{~cm}$ or to the depth of the former farmland. Three replicates were taken randomly at each station, pooled and sieved in the field through a $1 \mathrm{~mm}$ mesh sieve. The residue was preserved in $4 \%$ buffered formaldehyde solution and stained with Rose Bengal. In the lab specimens were sorted and identified to the lowest possible taxonomic level, counted, wet weighted and preserved. The number of individuals per species found at each station was converted to density (number of ind. $\mathrm{m}^{-2}$ ). Worm counts were based on the number of heads found in a sample. When only a tail was found it was recorded as 1 individual of this species. Biomass was calculated by converting total wet weight to total ash free dry weight (AFDW) in $\mathrm{g} \mathrm{m}^{-2}$ using species specific conversion factors as described in Craeymeersch and Escaravage (2014). Additional, lugworm Arenicola marina densities were counted in the field within $0.25 \mathrm{~m}^{2}$ quadrants $(n=10)$ at each sampling station.

At each stations elevation (NAP $\mathrm{m}$ ), median grain size $(\mu \mathrm{m})$, sediment size distribution (percentage coarse, medium, fine and very fine sand, and silt), bulk density $\left(\mathrm{g} \mathrm{cm}^{-3}\right)$ and depth of mud layer $(\mathrm{cm})$ were determined. Additional, Chlorophyll $a\left(\mu \mathrm{g} \mathrm{cm}^{-3}\right)$, as a measure for food availability for benthic animals, was measured by three pooled sediment samples collected from the upper $1 \mathrm{~cm}$ of the sediment, using a $1 \mathrm{~cm}$ in diameter syringe from which the tip was cut off. The samples were stored in the dark at $-80^{\circ} \mathrm{C}$ after which they were freeze dried and analysed spectrophotometrically according to Aminot and Rey (2000). At 15 stations also sediment penetration resistance $(\mathrm{N})$ and average erosion resistance $(\mathrm{kPa})(\mathrm{n}=5)$ of the sediment was measured.

\subsection{Comparison of the community structure in the managed realignment area versus natural tidal flats}

Since 1992 the Ministry of Transport, Public Works and Water Management is monitoring the benthic fauna of the Western Scheldt as part of a biological monitoring programme (MWTL). To compare community structure in the managed realignment area to that of natural nearby tidal flats, a subset of the MWTL data (based on location and ecotope) was used. The managed realignment area, located on the poly/mesohaline transition zone, can be classified as low dynamic mid litoral ecotope according to the Dutch ecotope system used in Scheldt estuary, the so-called ZES (Zoute Ecotopen Stelsel, Bouma 
et al. 2005). A total of 62 macrobenthic samples taken between 2010 and 2014, within the low dynamic mid litral ecotope between $3^{0} 59.659^{\prime} E$ and $4^{\circ} 6.550^{\prime} E$ ( 58000 and 66000 Rijksdriehoek) were used in the analysis (Figure 2).

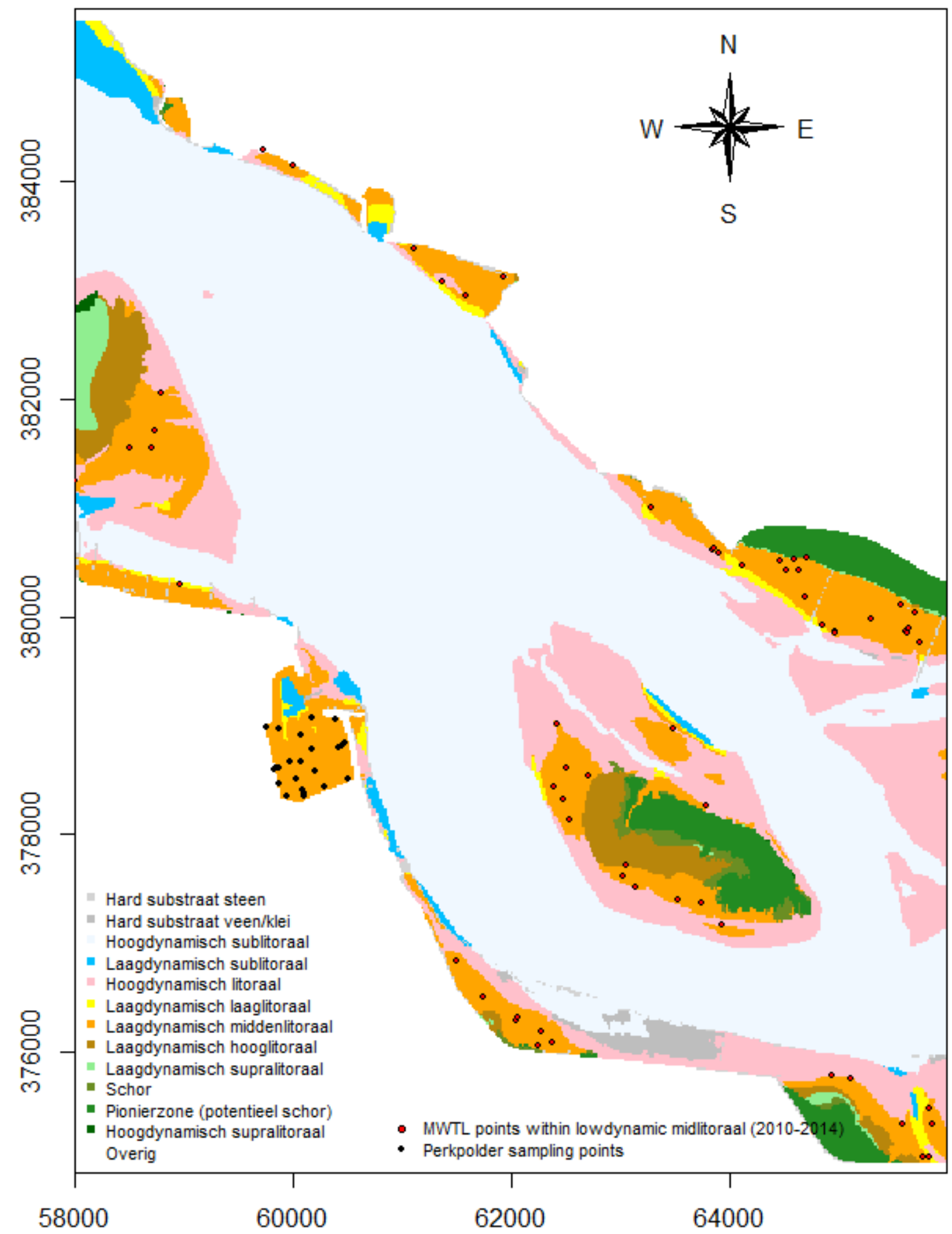

Figure 2. Map of the Scheldt estuary with 24 macrobenthic infauna sampling stations sampled for this report between 2015-2018 in the managed realignment area (black dots) and 62 macrobenthic sampling stations sampled as part of the MWTL programme between 2010-2014 within the low dynamic mid litoral ecotope (red dots).

\subsection{Birds}

During the first two years, counts of birds in the realignment site were made during low tide on seven occasions during the autumn and winter months (2016: Feb, Mar, 2*Oct, Nov, Dec; 2017: Jan). No 
attempt was made to establish a reference area on which bird counts would be made. From September 2017 onwards the methodology changed in low and high tide bird counts during each calendar month. Only the data from September 2017 onwards have been analysed. Behaviour of the birds were recorded separately distinguishing foraging birds from resting birds and birds that use the surrounding dike as roosting area. For the top ten waders, diet data was obtained from Leopold et al. (2004) and plotted versus the available food source. During each count all humans and dogs using the surrounding dikes and tidal flat were counted. No comparison was made with nearby tidal flats, as low water bird counts were not available in the Westerschelde.

\subsection{Statistical analysis}

\section{Development of the community structure in Perkpolder}

A multivariate analysis was performed to assess the development of the community structure of the macrobenthic infauna. To avoid ambiguity, specimens that had only been determined at class or phylum level were left out for the multivariate analysis of the community composition. Nemertea and Oligochaeta were included. If not all individuals of a genus were identified at the species level, they were merged to the genus level. The species name was then added in parentheses when only one species was identified within the genus in all samples, whereas spp. was used when multiple species were present. The community structure was analysed using multivariate statistics using the package 'vegan' (Oksanen et al. 2018) in R (R Core Team, 2018). A Bray-Curtis similarity matrix was constructed from fourth root-transformed densities of the macrobenthic taxa with a dummy variable (with a value of 1 ) to overcome the problems associated with the complete absence of organisms at one station inside the realignment site in autumn 2018. A Non-metric multidimensional scaling (NMDS) was applied to the similarity matrix to represent, as closely as possible, the pairwise (dis)similarity between objects in a two-dimensional space. NMDS is a rank-based approach. This means that the original distance data is substituted with ranks.

Detrended Correspondence Analysis (DCA) was used to detect the length of the environmental gradient. After DCA, Canonical Correspondence Analysis (CCA) was applied and the Monte Carlo permutation test used to reveal the effect of the obtained explanatory variables on macrobenthic infauna species composition. A total of 999 permutations were performed.

\section{Explanatory environmental variables}

To explore how species and community traits varied with environmental characteristics as well as through time additional multivariate analyses were conducted using the R package "mvabund" (Warton 2011). Multivariate generalized linear models where used to examine environmental drivers of abundance, biomass, and presence/absence as they allowed to run linear models on all taxa responses simultaneously. Only the 20 most abundant taxa where included in the models. To obtain significance of environmental explanatory variables, ANOVAs were run and resampled 999 times for each model. Two sets of models were run, one with environmental characteristics (elevation, mud depth, penetration resistance, chlorophyll, bulk density, median grain size, and very fine grain fraction) and one with year, season, and sampling station. Model fits were checked using residual plots. For the presence/absence and abundance model a binomial and negative binomial distribution was used respectively.

\section{Community traits}

To examine which traits best explained variation across taxa in their environmental response, trait based models were used. For 22 taxa species specific traits were obtained from the BIOTIC database (Marlin, 2016) and from literature. A total of 12 traits were evaluated, including feeding, mobility, size, position in sediment, longevity, bioturbation/bioirrigation, reproductive and productivity traits. Each trait consists of different modalities (e.g. for the trait 'feeding', the modalities are: omnivore, surface deposit feeder, subsurface deposit feeder and filter feeder).

The trait based models were generalized linear models that examined interactions between traits and environmental variables. To test for the significance of interactions between environmental variables and traits ANOVAs were run on the models. Models were compared using the Akaike Information Criterion (AIC). 


\section{Results}

\subsection{Morphological changes}

\section{Area-wide spatial and temporal morphological changes}

The full coverage sampling campaign allowed to evaluate how sediment characteristics changed spatially at a fine resolution. Spatial distributions of bulk density, changes in elevation and sediment characteristics were in general related to the location of the inlet and the two main creeks. In 2016, bulk density ( $\mathrm{g}$ sediment per sampled $\mathrm{cm}^{-3}$ ) was highest near the inlet and upper creeks and lower throughout the rest of the site, especially in the middle and bottom left corner (Figure 3). Most change occurred during the first two year (2016 and 2017) followed by almost no changes in 2018. Other sediment characteristics showed patterns driven by the distance to creaks and the inlet. Changes in elevation were larger near the inlet and in the middle of the site, compared to directly next to or at the creeks (Figure 4). The mud depth layer, mud content (Figure 5), and water content were lowest near the inlet and next to the creeks. Besides the creeks and inlet, another interesting feature was the upper left corner between the wall and the creek which had the highest bulk density, elevation and grain size in 2016. This area tended to change in the direction of the central values for each sediment characteristic over time. For most of the sediment characteristics, it was the only area that changed in a direction opposing that of the rest of the site.

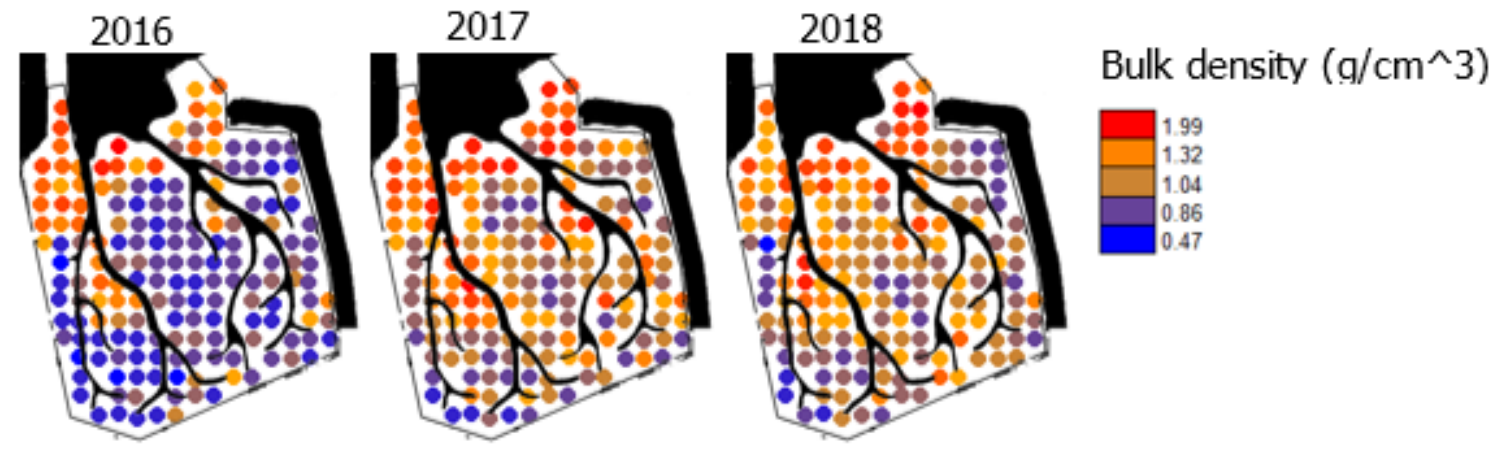

2016-2018

Difference

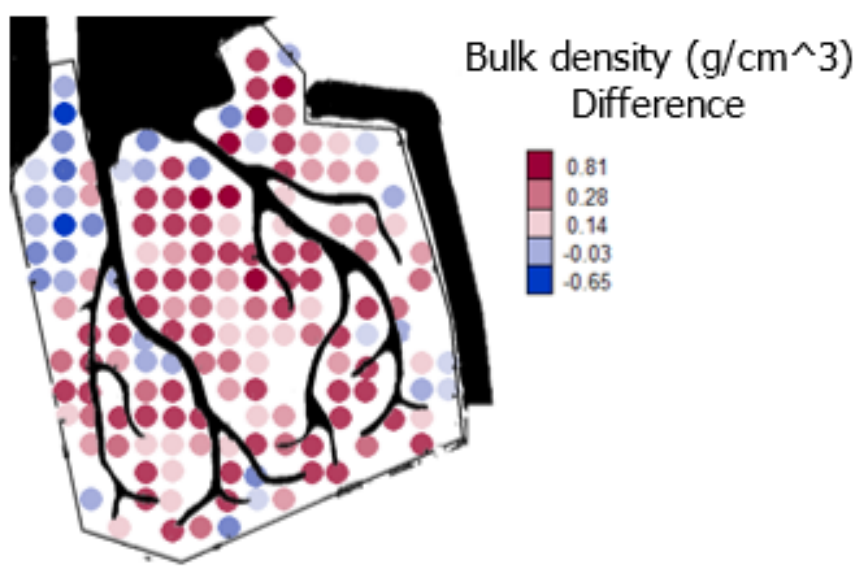

Figure 3. Sediment bulk density $\left(\mathrm{g} \mathrm{cm}^{-3}\right)$ measured in 2016, 2017, and 2018 at 200 equally spaced sampling points in Perkpolder (upper panel). The lower panel shows the differences between 2018 and 2016 (negative change in blue and positive change in red). 

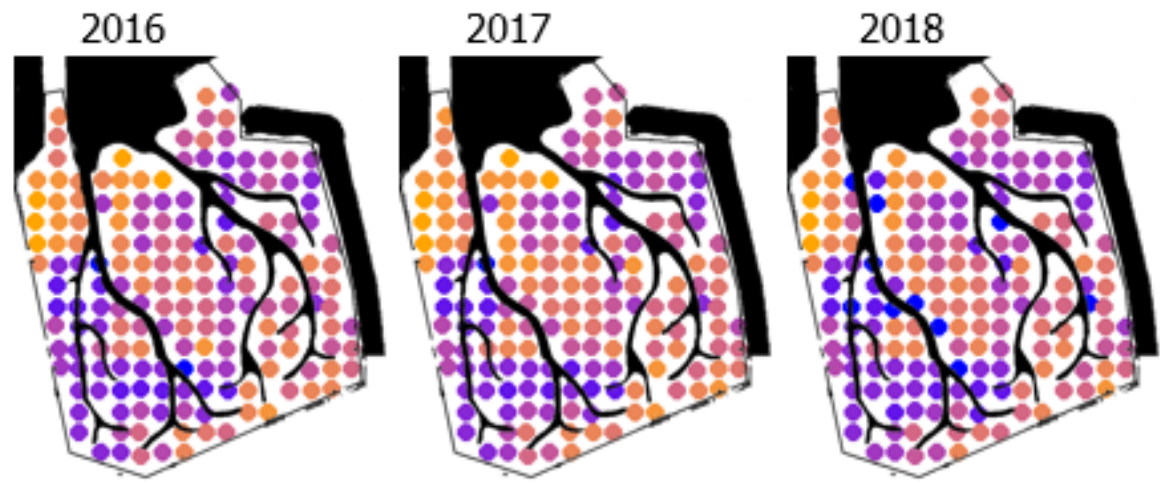

Elevation (NAP m)

\section{6-2018}

\section{Difference}

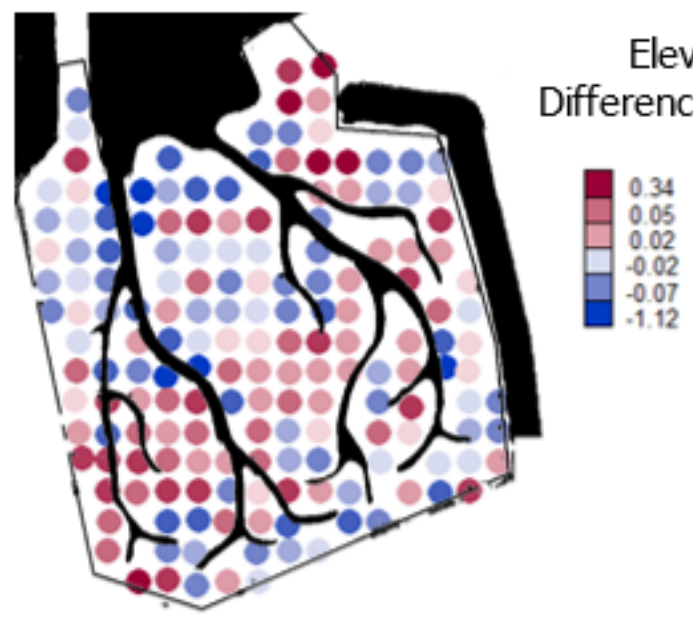

Figure 4. Sediment elevation values (NAP m) measured in 2016, 2017, and 2018 at 200 equally spaced sampling points in Perkpolder (upper panel). The lower panel shows the differences between each set of two years (negative change in blue and positive change in red) and the overall change in elevation over the time period. 


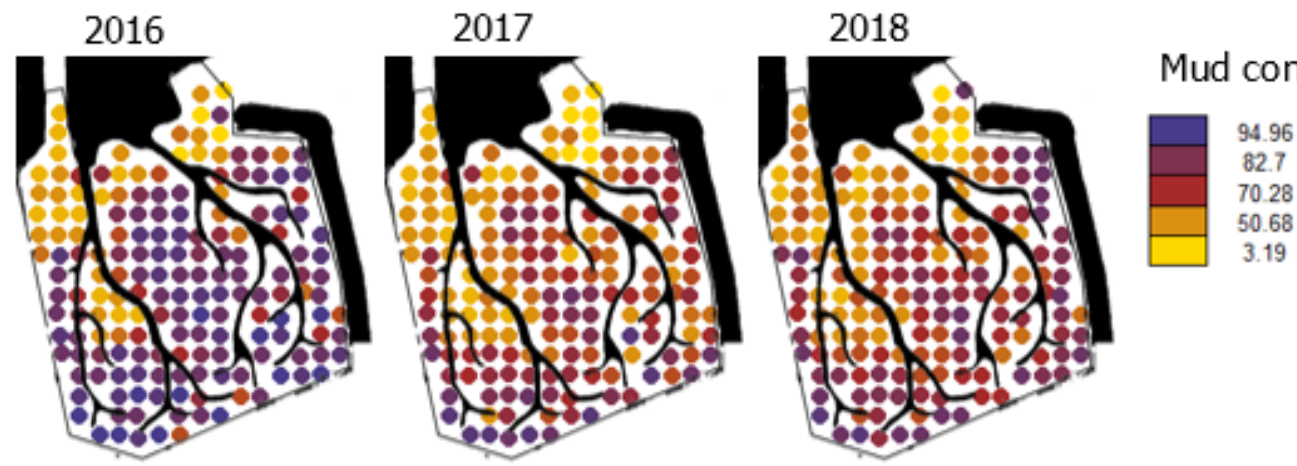

2016-2018

Difference

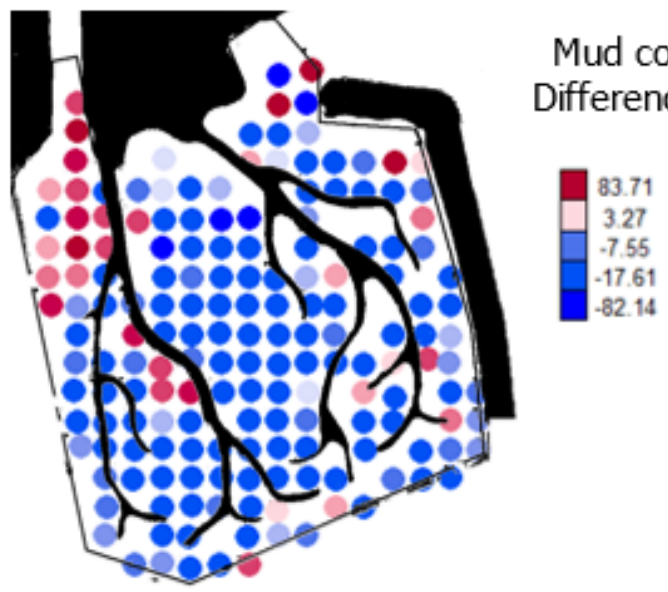

Figure 5. Sediment mud content (\%) measured in 2016, 2017, and 2018 at 200 equally spaced sampling points in Perkpolder (upper panel). The lower panel shows the differences between each set of two years (negative change in blue and positive change in red) and the overall change in mud content over the time period.

Spatial and temporal morphological changes at the benthic macrofauna sampling stations

After inundation, sediment with a high percentage of silt deposited in the managed realignment (Figure 6 ). Whereas the deposited mud layer on top of the former farmland changed in thickness over time, as measured with a ruler, elevation measurements do not reflect these changes as elevations stayed in the order of those recorded four months after the breach. An increase in deposited mud layer in 2016 and 2018 could indicate sedimentation in those years, whereas no large changes seems to occur in 2017. An increase in penetration resistance and a decrease in erosion resistance in time could indicate compaction of the sediment. Sediment density (Bulk density) however shows a decreases over time indicating that the sediment contains more water which is counter intuitive with respect to compaction. Chlorophyll a shows a peak in autumn 2016 and 2018. 

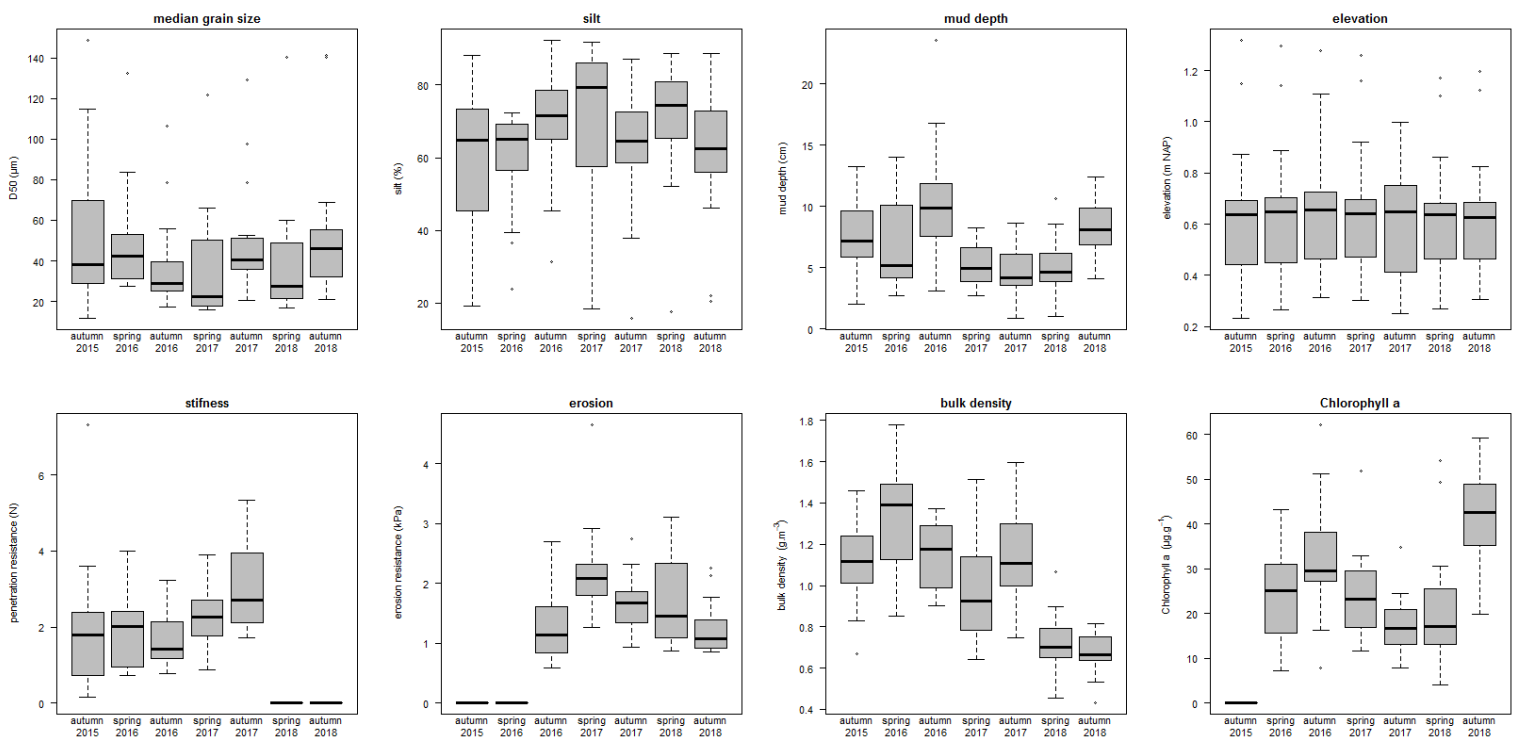

Figure 6. Sediment characteristics: Box plots of changes in median grain size, silt content, deposit mud layer, elevation, penetration resistance, erosion resistance, bulk density and chlorophyll-a in time within the managed realignment area.

\subsection{Colonization by macrobenthic infauna}

A total number of 61299 individuals belonging to 39 different taxa were collected in 126 samples taken within the managed realignment area between 2015 and 2018. A rapid colonization was observed as 19 species colonized the realignment area within four months after the breach. During each subsequent sampling campaign new species colonized the area (Table 1). During the first year, all sampling stations exhibited a large number of small opportunistic, highly mobile benthic species, mainly of the class Malacostraca (including crabs, lobsters, hermit crabs, isopods, amphipods, etc.). Corophium volutator, an amphipod, maximum size $11 \mathrm{~mm}$, was by far the most dominant species in abundance and biomass (Table 2). After one year larger sized long living species colonized the area with species from the class Polychaeta (bristle worms) dominating the area. The mean number of species per station was on average 10 , in same order as found on nearby tidal flats (Figure 7A). Only at one station in autumn 2018, no species were found. Total abundance increased during the first year after the breach, followed by a decrease, resulting in an average abundance comparable to that of the nearby tidal flats (Figure 7B). The managed realignment was dominated by Malacostraca and Polychaeta of which the amphipd Corophium volutator, and the bristle worms Pygospio elegans and Heteromastus filiformis contributed most to the total abundance. Biomass (Figure 7C) increased over time. During the first two sampling campaigns malacostraca accounted for the majority of the biomass whereas from autumn 2016 onwards polychaetes and bivalves contributed most to the total biomass. Biomass in autumn 2018 is $63 \%$ higher compared to nearby tidal flats. This is mainly due to high abundance of the bristle worms Heteromastus filiformis and Hediste diversicolor which contribute most to the total biomass.

\subsection{Community structure}

The benthic community composition showed high dissimilarity between sampling moments inside the realignment site indicating that after three years the community is still changing (Figure 8). The community development shows seasonality and develops in the direction of the community found on nearby tidal flats in the Western Scheldt. Development of the community structure was significantly affected by time ( 7 sampling moments in time) $\left(F_{6,119}=21.76, p=0.001\right)$ and season $\left(F_{1,124}=5.56\right.$, $\mathrm{p}=0.002$ ) which explained $21.6 \%$ and $6.2 \%$ of the variability, respectively (Figure 9 ). 
Table 1. Occurrence (\% of the total sampled stations) of the observed species/taxon in the managed realignment Perkpolder (2015-2018) and on nearby natural tidal flats (MWTL data) sampled between 2010-2014.

\begin{tabular}{|c|c|c|c|c|c|c|c|c|}
\hline \multirow[b]{2}{*}{ species/Taxon } & \multicolumn{8}{|c|}{ Occurrence \% } \\
\hline & $\begin{array}{c}\text { Autumn } \\
2015\end{array}$ & $\begin{array}{c}\text { Spring } \\
2016\end{array}$ & $\begin{array}{c}\text { Autumn } \\
2016\end{array}$ & $\begin{array}{c}\text { Spring } \\
2017\end{array}$ & $\begin{array}{c}\text { Autumn } \\
2017\end{array}$ & $\begin{array}{c}\text { Spring } \\
2018\end{array}$ & $\begin{array}{c}\text { Autumn } \\
2018\end{array}$ & $\begin{array}{c}\text { MWTL } \\
2010-2014\end{array}$ \\
\hline Corophium volutator & 100 & 100 & 100 & 100 & 100 & 83 & 22 & 56 \\
\hline Polydora cornuta & 94 & 31 & 88 & 88 & 50 & 22 & 70 & 11 \\
\hline Nemertea & 88 & 88 & 50 & 75 & 56 & 13 & 35 & 13 \\
\hline Oligochaeta & 88 & 81 & 38 & 25 & & & 4 & 11 \\
\hline Limecola balthica & 81 & 69 & 100 & 100 & 75 & 65 & 78 & 89 \\
\hline Pygospio elegans & 81 & 100 & 100 & 100 & 94 & 91 & 96 & 79 \\
\hline Eteone spp & 69 & 56 & 88 & 81 & 88 & 91 & 39 & 44 \\
\hline Alitta succinea & 50 & 63 & 81 & 94 & 94 & 83 & 43 & 2 \\
\hline Aphelochaeta & 50 & 38 & 75 & 50 & 63 & 43 & 39 & 13 \\
\hline Crangon crangon & 50 & 69 & 13 & 69 & 31 & 61 & 17 & 32 \\
\hline Heteromastus filiformis & 50 & 31 & 100 & 100 & 100 & 100 & 96 & 89 \\
\hline Streblospio benedicti & 44 & 6 & 63 & 13 & 44 & 48 & 83 & 60 \\
\hline Peringia ulvae & 38 & & 63 & 13 & 44 & 48 & 83 & 60 \\
\hline Chironomidae & 31 & & 13 & 6 & & & & \\
\hline Cyathura carinata & 31 & 31 & 69 & 63 & 94 & 91 & 91 & 58 \\
\hline Nudibranchia & 19 & & 6 & & & & & 3 \\
\hline Hediste diversicolor & 13 & 6 & 81 & 94 & 63 & 83 & 91 & 69 \\
\hline Insecta & 13 & 13 & 19 & & & 13 & 9 & 2 \\
\hline Scrobicularia plana & 6 & 6 & 6 & 13 & 44 & 61 & 83 & 35 \\
\hline Bivalvia & & 13 & & & 6 & & & 21 \\
\hline Gammarus & & 6 & & 6 & 6 & & & \\
\hline Polychaeta & & 6 & 6 & & & & & \\
\hline Pseudopolydora pulchra & & 6 & & & & & & \\
\hline Arenicola & & & 13 & 13 & & & 4 & 15 \\
\hline Alitta virens & & & 6 & & & & & \\
\hline Donax vittatus & & & 6 & & & & & \\
\hline Isopoda & & & 6 & & & & & 2 \\
\hline Mya arenaria & & & 6 & & & 4 & 9 & 5 \\
\hline Bathyporeia pilosa & & & & 6 & & 4 & & 29 \\
\hline Platyhelminthes & & & & 6 & & & & \\
\hline Carcinus maenas & & & & & 13 & & 26 & 3 \\
\hline Cerastoderma edule & & & & & 13 & 4 & 9 & 11 \\
\hline Ensis & & & & & 6 & & & 2 \\
\hline Gastropoda & & & & & & 4 & & \\
\hline Hemigrapsus & & & & & & & 22 & \\
\hline Abra tenuis & & & & & & & 13 & 3 \\
\hline Tapes & & & & & & & 4 & \\
\hline Corophium & & & & & & & & 32 \\
\hline Corophium arenarium & & & & & & & & 29 \\
\hline Tellinoidea & & & & & & & & 26 \\
\hline Arenicola marina & & & & & & & & 15 \\
\hline Capitella spp & & & & & & & & 10 \\
\hline Decapoda & & & & & & & & 8 \\
\hline Assiminea grayana & & & & & & & & 6 \\
\hline Marenzelleria & & & & & & & & 6 \\
\hline Cardiidae & & & & & & & & 5 \\
\hline Corophiidae & & & & & & & & 5 \\
\hline Eurydice pulchra & & & & & & & & 5 \\
\hline Parahaustorius holmesi & & & & & & & & 5 \\
\hline Abra tenuis & & & & & & & & 3 \\
\hline Monopseudocuma gilsoni & & & & & & & & 3 \\
\hline Abra alba & & & & & & & & 2 \\
\hline Bylgides sarsi & & & & & & & & 2 \\
\hline Capitellidae & & & & & & & & 2 \\
\hline Crangonidae & & & & & & & & 2 \\
\hline Enchytraeidae & & & & & & & & 2 \\
\hline Harmothoe glabra & & & & & & & & 2 \\
\hline Scolelepis bonnieri & & & & & & & & 2 \\
\hline Semelidae & & & & & & & & 2 \\
\hline number of specie & 19 & 20 & 25 & 21 & 20 & 20 & 24 & 49 \\
\hline
\end{tabular}


Table 2. Density (ind. $\mathrm{m}^{-2}$, mean \pm se) of the observed species/taxon in the managed realignment Perkpolder (2015-2018) and on nearby natural tidal flats (MWTL data) sampled between 2010-2014.

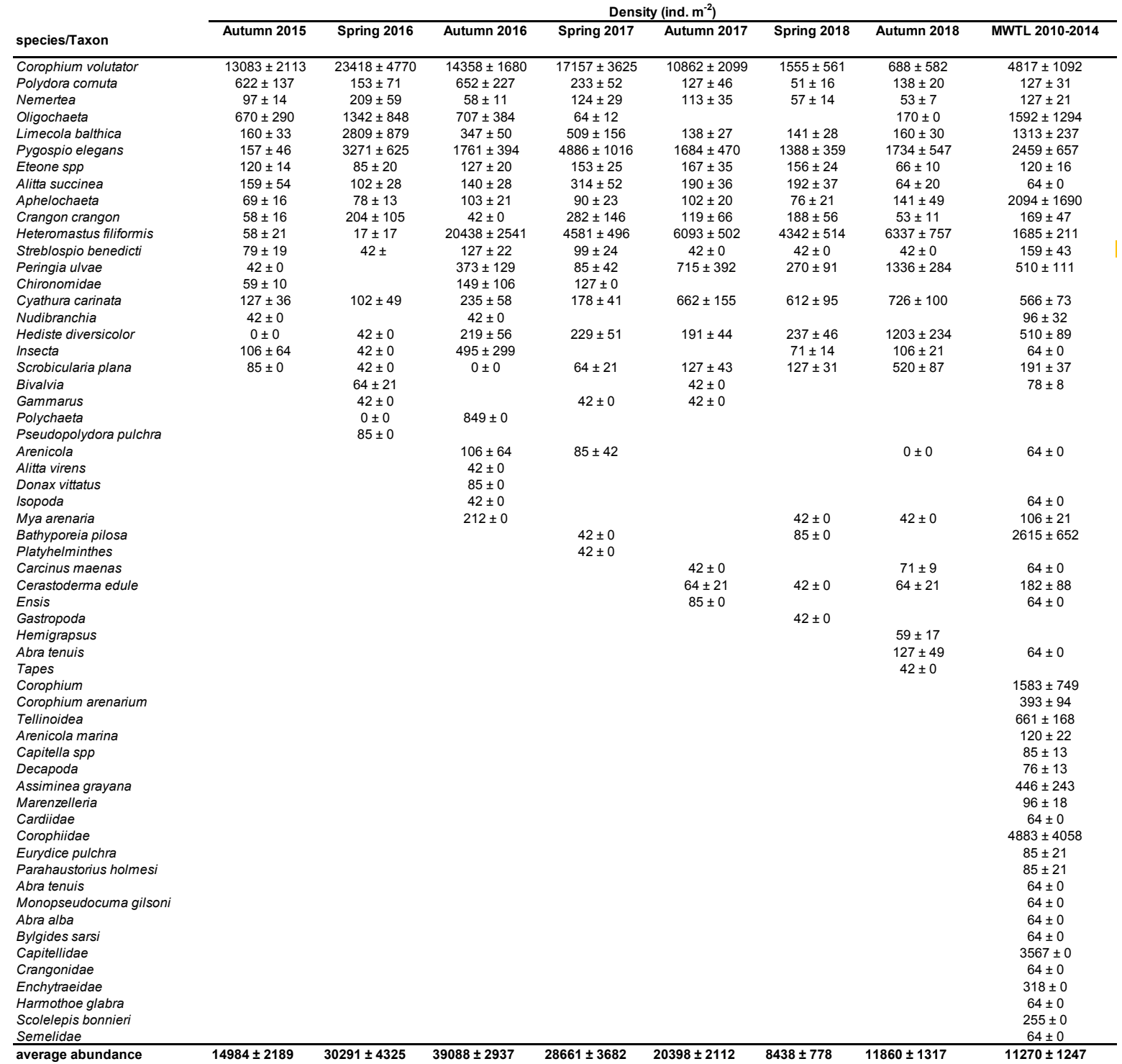




\section{A}
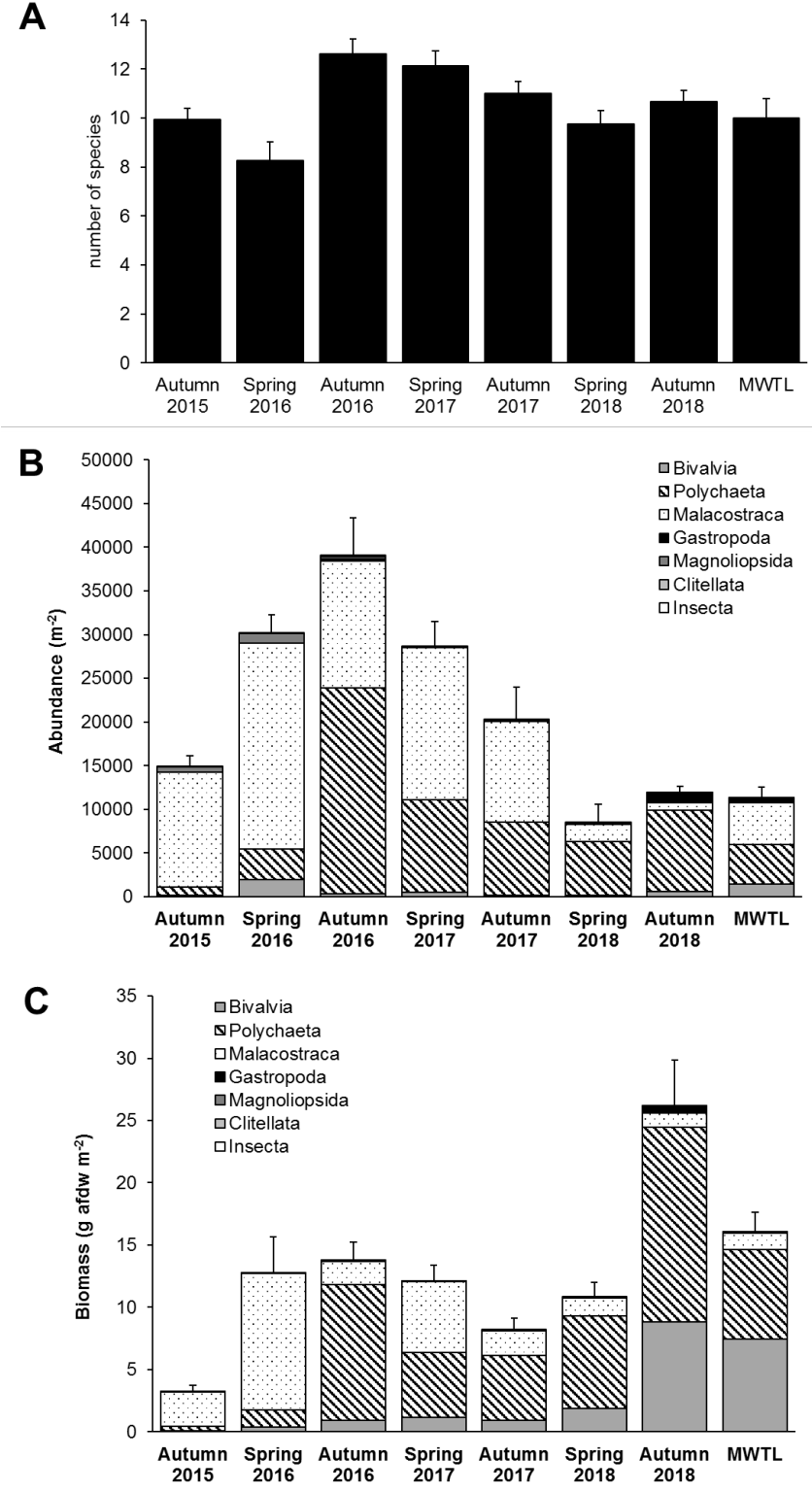

Figure 7. Variation in the mean ( \pm se) species richness $(A)$, total abundance $(B)$ and biomass $(C)$ with proportional representation of the taxa in the managed realignment area (Autumn 2015 till Autumn 2018) and in the MWTL data between 2010 and 2014. 


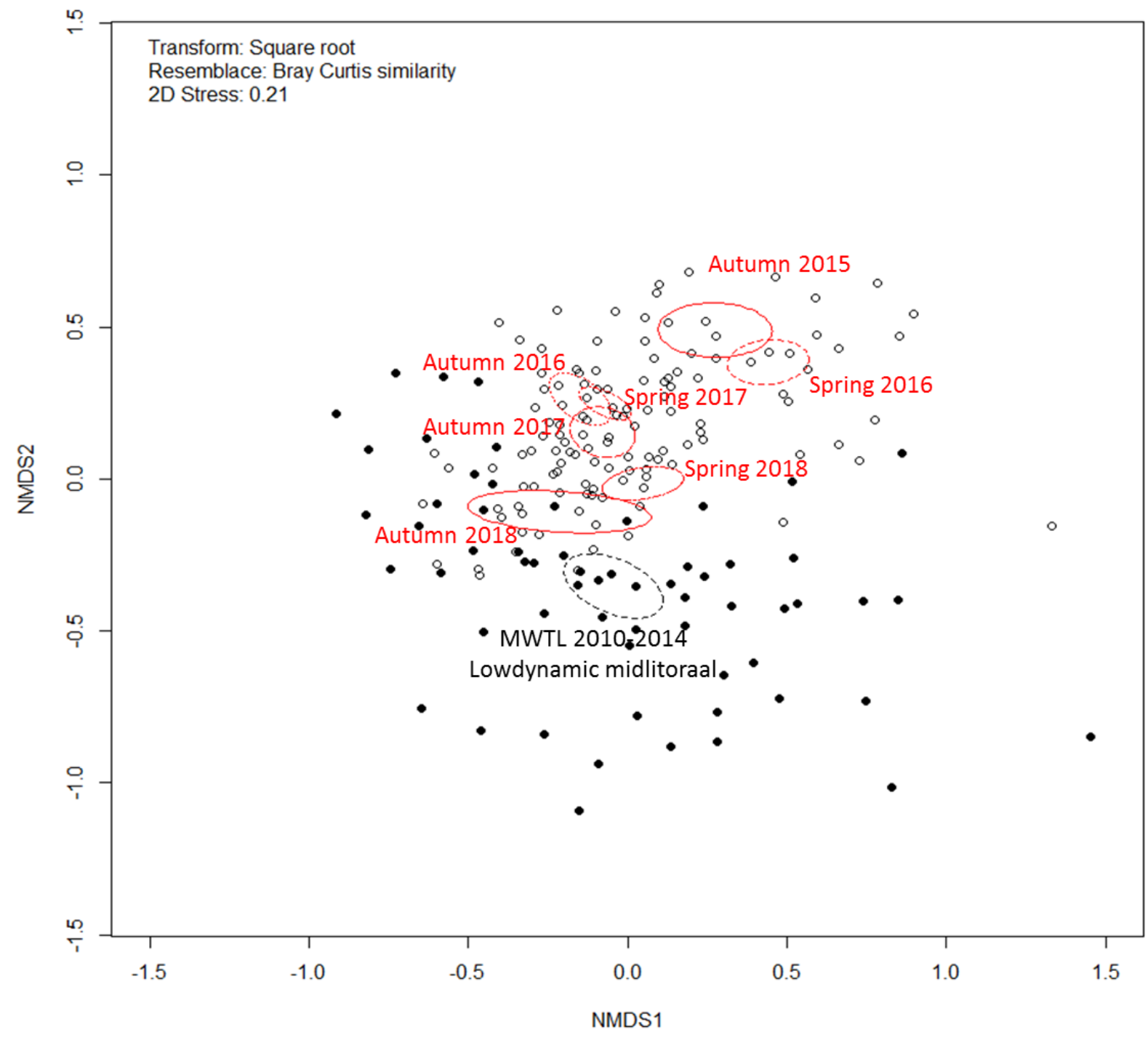

Figure 8. nMDS-plot showing changes in benthic community composition based on abundance data from autumn 2015 till autumn 2018 at the managed realignment Perkpolder (white dots) towards a community composition found at nearby tidal flats (black dots). Each point represents a sampling station. Distance between points is a measure of dissimilarity in benthic community composition. The eclipse (red = realignment area, black = nearby tidal flats) denote the $95 \%$ confidence interval for each sampling moment.
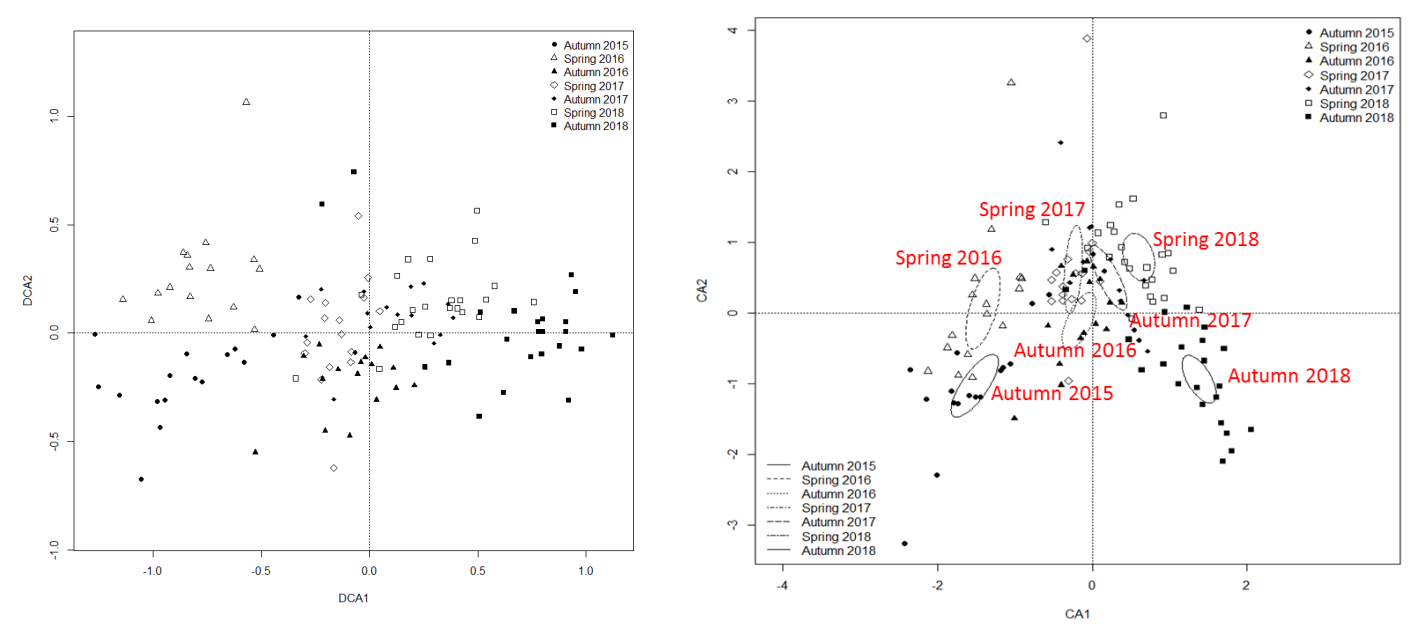
Figure 9. DCA (left) and CCA (right) ordination diagrams of species abundance per sampling moment. Community structure was significantly affected in time $\left(F_{6,119}=21.76, p=0.001\right)$ and season $\left(F_{1,124}=\right.$ $5.56, p=0.002$ ) which explained $21.6 \%$ and $6.2 \%$ of the variability, respectively.

\subsection{Environment and traits}

The area was first colonized by small, short-lived (except long-lived Oligochaeta: annelid worms), highly mobile taxa (except polychaete tube dweller Pygospio elegans) with high $\mathrm{P}$ to B ratios (Figure 10 and Figure 11). These taxa live within the top five centimeters of the surface and are surface deposit feeders (except sub-surface deposit feeding Oligochaeta). Oligochaeta were highly abundant at the beginning of the sampling period, but decreased dramatically starting in spring 2017 (Figure 12). Over the course of the monitoring period, the community shifted to larger, longer lived, and more productive taxa which correspond mostly to bivalves, especially Scrobicularia plana, the peppery furrow shell. A notable decrease in abundance of these shorter lived species, mostly the amphipod Corophium volutator, occurred in 2018 which coincided with a drop in average bulk density of the area (Figure 12 and Figure 6). A spike in chlorophyll in autumn 2016 (Figure 6) coincided with a large increase in the bristle worm Heteromastus filiformis abundance as well as an increase in the modality 'medium' ( $\mathrm{nr} 2$ ) and 'large' ( $\mathrm{nr}$ 3 ) of the size trait. After autumn 2016, the large benthos category has a stable mean abundance until autumn 2018 where the abundance of large benthos increases coinciding with the spike in chlorophyll a (Figure 10 and Figure 6).
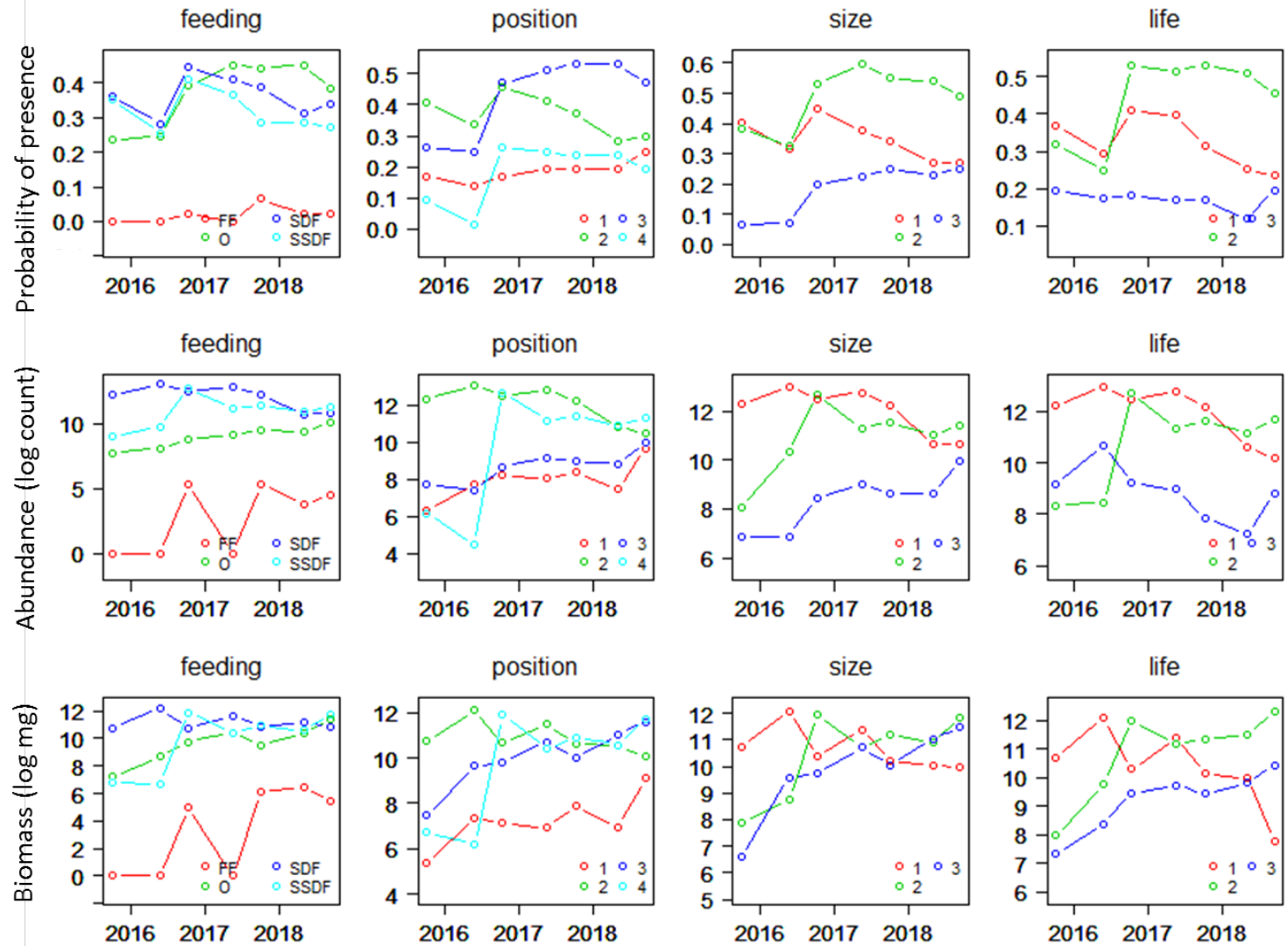

Figure 10. Presence, abundance and biomass of feeding, position, size and life traits modalities averaged over the sampling moments. For the explanation of the trait legends, see Table 3. 

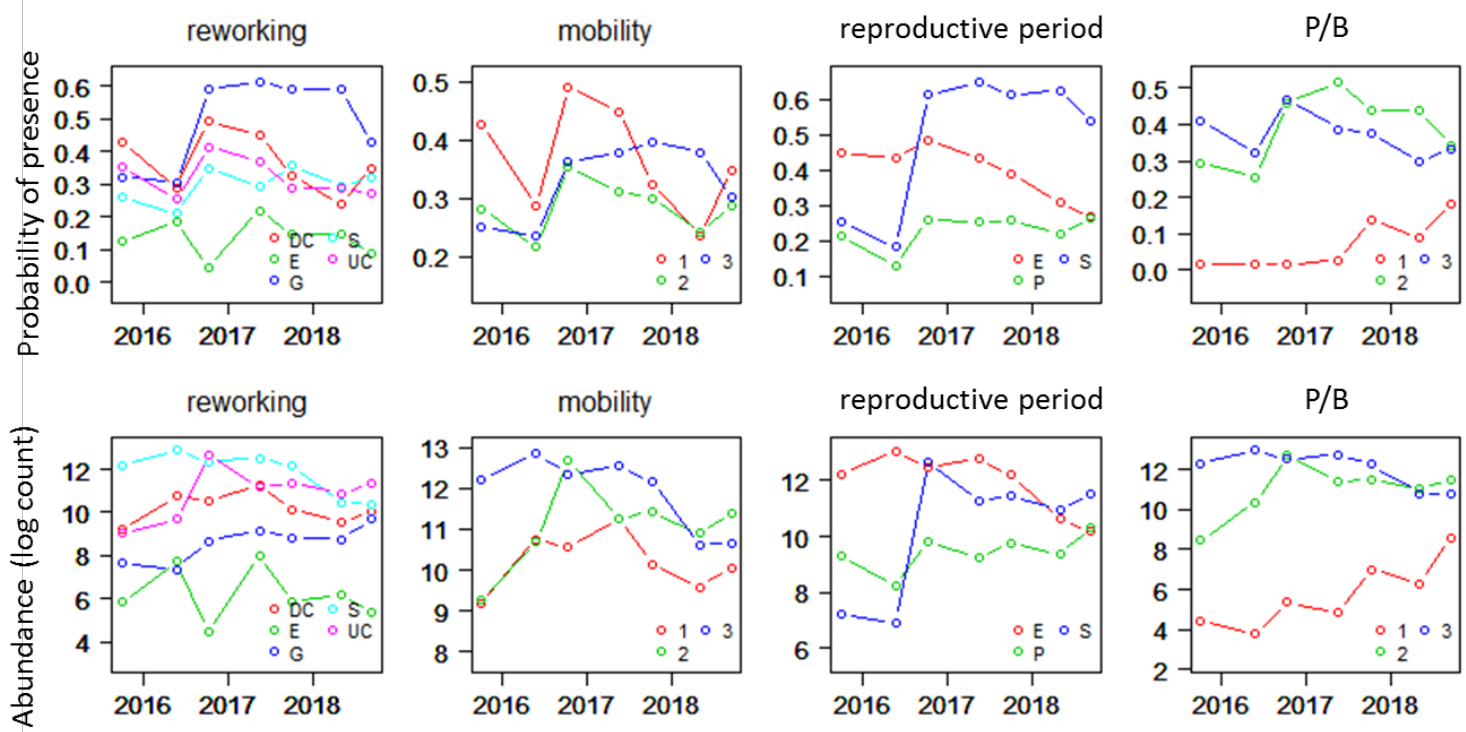

reproductive period
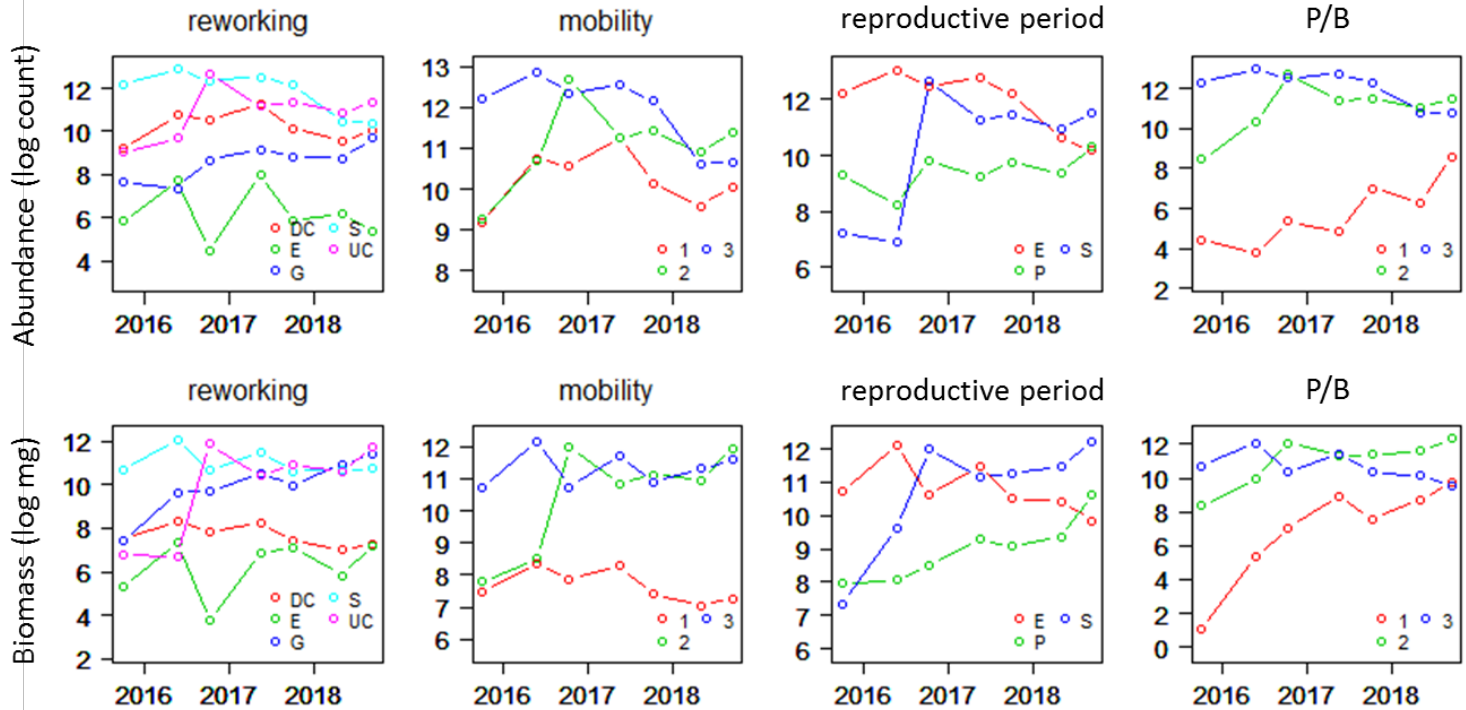

Figure 11. Trait modalities of Presence, abundance and biomass of reworking, mobility, reproductive period and $P / B$ traits averaged over the sampling moments. For the explanation of the trait legends, see Table 3.

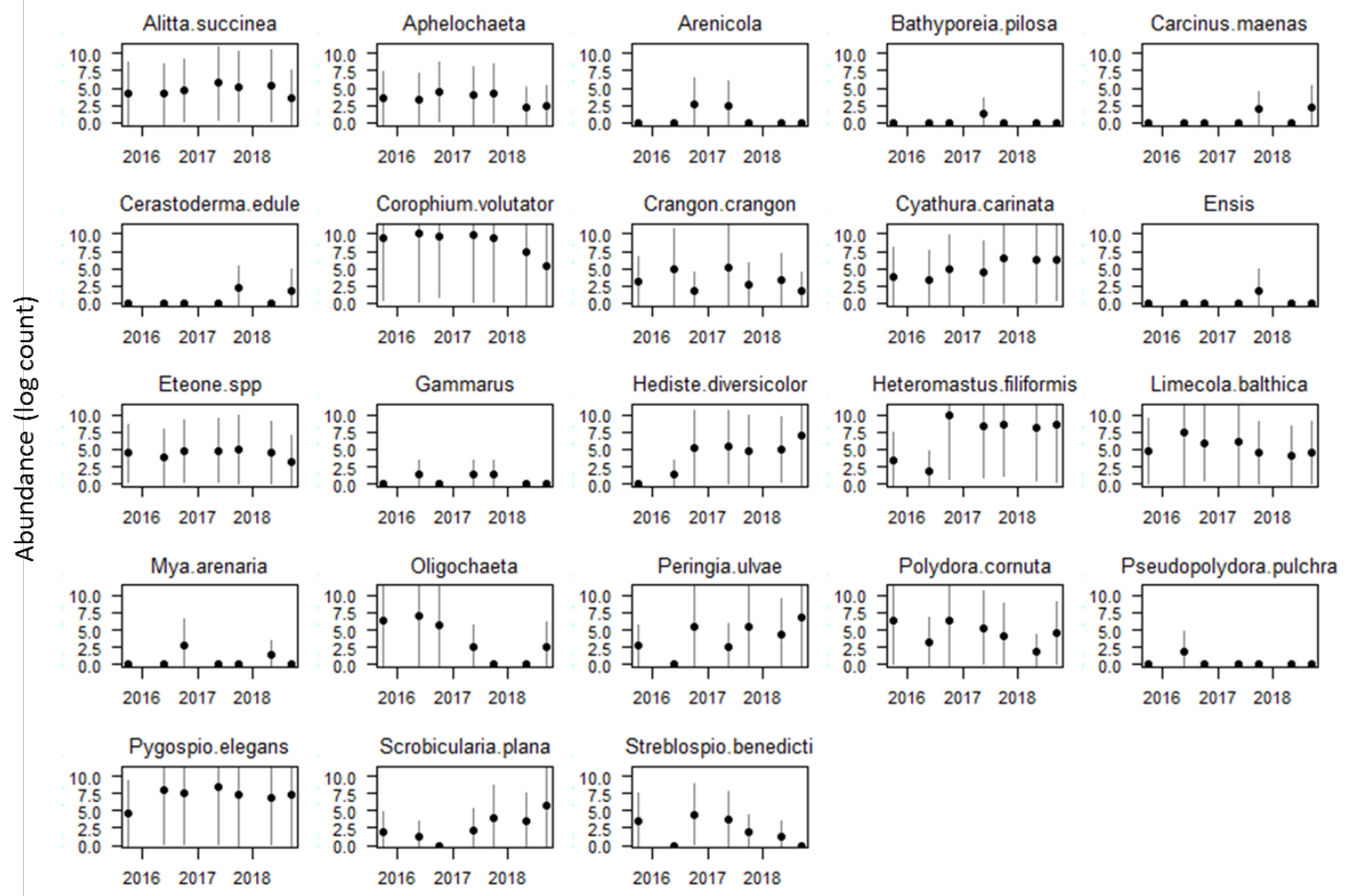

Figure 12. Average abundance (log count) of 23 taxa included in the trait-based analysis at each sampling moment \pm standard deviation (vertical lines black lines). 
Bulk density (ratio dry weight to the sampled volume)was the most important sediment characteristic in explaining taxa abundance, biomass, and presence/absence (Tables 4, 5, and 6). It was also one of the sediment characteristics that showed the clearest trend as it decreased over the sampling period (Figure 6). Bulk density had a significant positive effect on the presence of smaller, shorter lived taxa (C. volutator, Oligochaeta , P. elegans) and a negative effect on longer lived and deeper dwelling taxa (S. plana, $H$. diversicolor, $H$. filiformis) (Table 4). Peringia ulvae, the mudsnail, is the only abundant epifaunal diatom grazer that was less present with increases in bulk density. As could be expected, chlorophyll a had a significant positive effect on $P$. ulvae abundance (Table 5). Chlorophyll had a significant negative relationship with the biomass of $C$. volutator and $P$. elegans, the early dominant small, shorter lived taxa. Mud depth was a significant explanatory variable for both biomass and abundance of deeper dwelling polychaetes, such as Heteromastus filiformis and $H$. diversicolor. The only taxon for which a significant negative effect of mud depth on abundance and biomass was found is the polychaete Alitta succinea. The very fine sand fragment had a consistent significant negative effect on biomass and abundance of Streblospio benediciti, though no significant relationship between grain size and biomass or abundance of the other 2 spionid polychaete species ( $P$. elegans and Polydora cornuta) was found.

Taxa abundances varied more on a temporal scale than over a spatial one (Table 7). The taxa with only a significant seasonal effect are the bristle worms Aphelochaeta, the brown shrimp Crangon crangon, and the bristle worm Polydora cornuta, which all had lower abundance in spring. The taxa with a significant year effect only, with the exception of Oligochaeta, increased over the sampling period (Cyathura carinata, H. diversicolor, and S. plana).

The trait-based analysis revealed interactions, or how benthos trait response changed as the environment changed. Bulk density and penetration resistance had the greatest number of interactions with benthos traits (Figure 13). Chlorophyll content did not have any interactions with the traits, however it had strong positive effects on long-lived taxa and sub-surface deposit feeders, which confirms what we observed from the multivariate generalized linear models. The reworking trait had interactions with both elevation and the very fine sediment fraction, both of which are environmental variables that reflected spatial variability over temporal variability.

A

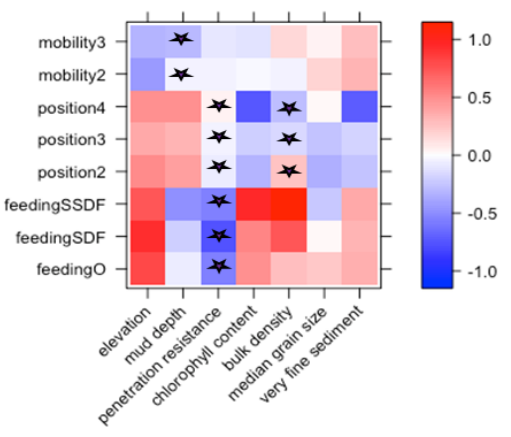

B

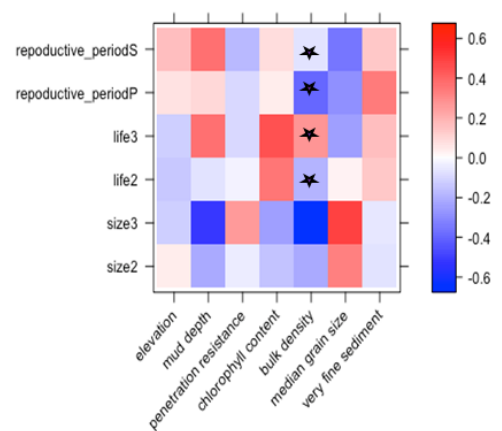

C

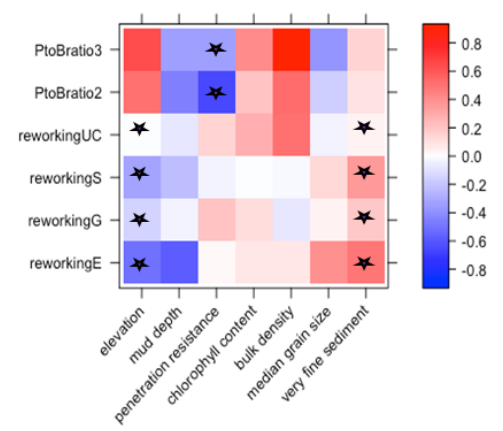

Figure 13. Coefficient heat map for trait-based analysis of taxa abundance. Refer to Table 3 for explanation of traits and modalities. A, B, and C are separate models as all the coefficients traits could not be included in one model because of restricted degrees of freedom. $(A)$ is the best model by AIC. The stars indicate significant $(p<0.1)$ interactions between a trait and an environmental variable. 
Table 3. Traits of species/taxa used in the traits-based multivariate analysis. Traits for rare species were not included. Feeding modalities: $\mathrm{O}=$ omnivore, SDF=surface deposit feeder, SSDF = subsurface deposit feeder, FF= filter feeder; Position: $1=$ epifauna, $2=$ shallow $(0-5 \mathrm{~cm}), 3=$ middle $(5-15 \mathrm{~cm}), 4=$ deep $(.15$ $\mathrm{cm})$; Life: 1= short, $2=$ medium, 3= long; Size: $1=$ small $(<0.001 \mathrm{~g}), 2=$ medium $(0.001-0.01 \mathrm{~g})$, 3 =large $(0.01-0.14 \mathrm{~g})$; Reworking: $\mathrm{E}=$ epifauna biodiffuser, $\mathrm{S}=$ surficial biodiffuser, $\mathrm{DC}=$ downward conveyor, $\mathrm{UC}=$ upwords conveyor, $\mathrm{G}=$ gallery biodiffusor; Mobility: $1=$ sessile, $2=$ limited, $3=$ free; Reproductive period: $\mathrm{S}=$ Semelparous, $\mathrm{E}=$ episodic, $\mathrm{P}=$ Protracted; $\mathrm{P} / \mathrm{B}, 1=$ low ( $<1 /$ year), $2=$ medium (1-3/year), 3=high (>3/year). Traits for C. carinata (Ferreira et al., 2004; Queirós et al., 2013), for Oligochaeta size and position (Ysebaert et al., 2005) lifespan and P/B ratio (Giere, 2006).

\begin{tabular}{|c|c|c|c|c|c|c|c|c|}
\hline & Feeding & Position & Size & Life & Reworking & Mobility & $\begin{array}{l}\text { Repoductiv } \\
\text { e period }\end{array}$ & $\mathrm{P} / \mathrm{B}$ \\
\hline Alitta succinea & SDF & 3 & 3 & 2 & G & 3 & S & 2 \\
\hline Aphelochaeta & SDF & 2 & 1 & 2 & S & 2 & $\mathrm{E}$ & 3 \\
\hline Arenicola & SSDF & 4 & 3 & 3 & UC & 2 & E & 2 \\
\hline Bathyporeia pilosa & SDF & 2 & 1 & 1 & S & 3 & $P$ & 2 \\
\hline Carcinus maenas & $\mathrm{O}$ & 1 & 3 & 3 & E & 3 & $P$ & 1 \\
\hline Cerastoderma edule & $\mathrm{FF}$ & 2 & 3 & 3 & $S$ & 3 & $\mathrm{P}$ & 1 \\
\hline Corophium volutator & SDF & 2 & 1 & 1 & $S$ & 3 & E & 3 \\
\hline Crangon crangon & 0 & 1 & 2 & 2 & $\mathrm{E}$ & 3 & $\mathrm{P}$ & 2 \\
\hline Cyathura carinata & 0 & 2 & 2 & 2 & $S$ & 3 & $\mathrm{P}$ & 3 \\
\hline Ensis & $\mathrm{FF}$ & 4 & 3 & 3 & S & 2 & E & 1 \\
\hline Eteone spp & 0 & 3 & 1 & 2 & G & 3 & $P$ & 2 \\
\hline Gammarus & SDF & 1 & 1 & 1 & $\mathrm{E}$ & 3 & $P$ & 3 \\
\hline Hediste diversicolor & 0 & 3 & 3 & 2 & G & 3 & $S$ & 2 \\
\hline $\begin{array}{l}\text { Heteromastus } \\
\text { filiformis }\end{array}$ & SSDF & 4 & 2 & 2 & UC & 2 & $S$ & 2 \\
\hline Limecola balthica & SDF & 2 & 2 & 3 & $S$ & 2 & $E$ & 2 \\
\hline Mya arenaria & $\mathrm{FF}$ & 4 & 3 & 3 & $S$ & 2 & $P$ & 1 \\
\hline Oligochaeta & SSDF & 2 & 1 & 3 & UC & 2 & E & 3 \\
\hline Peringia ulvae & SDF & 1 & 1 & 2 & $S$ & 3 & $P$ & 3 \\
\hline Polydora cornuta & SDF & 2 & 1 & 1 & DC & 1 & $P$ & 3 \\
\hline $\begin{array}{l}\text { Pseudopolydora } \\
\text { pulchra }\end{array}$ & SDF & 2 & 1 & 1 & DC & 1 & $P$ & 3 \\
\hline Pygospio elegans & SDF & 2 & 1 & 1 & DC & 1 & $\mathrm{E}$ & 3 \\
\hline Scrobicularia plana & SDF & 3 & 3 & 3 & $S$ & 2 & $P$ & 1 \\
\hline Streblospio benedicti & SDF & 2 & 1 & 1 & DC & 1 & $\mathrm{P}$ & 3 \\
\hline
\end{tabular}


Table 4. The coefficients for the multivariate generalized linear model of taxa presence explained by sediment characteristics. Significant negative coefficients are highlighted in blue, significant positive coefficients are highlighted in orange. The significance levels are: $0.1>*>0.05>* *>0.01>* * *$

\begin{tabular}{|c|c|c|c|c|c|c|c|c|}
\hline & (Intercept) & $\begin{array}{c}\text { elevatio } \\
n\end{array}$ & $\begin{array}{l}\text { mud } \\
\text { depth }\end{array}$ & $\begin{array}{l}\text { penetration } \\
\text { resistance }\end{array}$ & $\begin{array}{c}\text { chlorophyll } \\
\text { content }\end{array}$ & $\begin{array}{l}\text { bulk } \\
\text { density }\end{array}$ & $\begin{array}{l}\text { median } \\
\text { grain size }\end{array}$ & $\begin{array}{l}\text { very fine } \\
\text { sediment }\end{array}$ \\
\hline Alitta succinea & 5.38 & -1.50 & 0.01 & -0.26 & -0.04 & -0.35 & $-0.01 *$ & -0.03 \\
\hline Aphelochaeta & -2.64 & -3.01 & 0.15 & $0.56 * *$ & 0.00 & $2.01 * *$ & 0.00 & 0.01 \\
\hline Corophium volutator & -2.45 & 1.65 & 0.25 & 0.56 & $-0.33 * * *$ & $23.14 * * *$ & -0.06 & -0.13 \\
\hline Crangon crangon & -0.21 & $-1.3 *$ & -0.07 & -0.24 & -0.01 & 0.54 & 0.01 & 0.04 \\
\hline Cyathura carinata & 1.38 & -0.15 & 0.11 & 0.30 & -0.02 & $-1.8 *$ & -0.01 & 0.04 \\
\hline Eteone.spp & 2.56 & -2.15 & 0.09 & $0.23 *$ & -0.03 & 0.71 & 0.01 & $-0.07 * *$ \\
\hline Hediste diversicolor & 1.33 & -0.45 & 0.04 & 0.11 & 0.02 & $-2.09 * *$ & 0.01 & 0.00 \\
\hline Heteromastus filiformis & 6.43 & -0.28 & 0.00 & 0.54 & -0.03 & $-3.92 * * *$ & -0.01 & -0.01 \\
\hline Limecola balthica & 0.97 & 0.09 & $0.13 *$ & -0.33 & -0.02 & 0.98 & 0.00 & -0.01 \\
\hline Nemertea & -1.60 & $-2.56 * *$ & 0.07 & 0.46 & -0.01 & $2.8^{* * *}$ & 0.00 & -0.01 \\
\hline Nereis & -1.97 & 0.20 & -0.03 & -0.08 & 0.02 & 0.68 & 0.01 & 0.01 \\
\hline Oligochaeta & -3.16 & -0.94 & -0.01 & -0.69 & -0.02 & $6.58 * * *$ & 0.01 & -0.14 \\
\hline Peringia ulvae & 1.28 & -0.15 & 0.02 & $-0.28 *$ & 0.01 & $-1.76 * *$ & 0.00 & 0.01 \\
\hline Polydora cornuta & -5.38 & 3.17 & 0.12 & 0.42 & $0.06 * *$ & 0.75 & -0.03 & 0.05 \\
\hline Pygospio elegans & -2.90 & -0.83 & 0.01 & -0.16 & 0.04 & $3.51 *$ & -0.02 & 0.24 \\
\hline Scrobicularia plana & -0.09 & -0.18 & -0.12 & 0.24 & 0.02 & $-4.16 * * *$ & -0.02 & $0.18 * * *$ \\
\hline Streblospio benedicti & -2.30 & 0.17 & $0.41 * * *$ & 0.24 & -0.02 & 3.09 & $-0.02 * *$ & $-0.24 * * *$ \\
\hline
\end{tabular}

Table 5. The coefficients for the multivariate generalized linear model of taxa abundance explained by sediment characteristics. Significant negative coefficients are highlighted in blue, significant positive coefficients are highlighted in red. The significance levels are: $0.1>*>0.05>* *>0.01>* * *$

\begin{tabular}{|c|c|c|c|c|c|c|c|c|}
\hline & (Intercept) & elevation & $\begin{array}{l}\text { mud } \\
\text { depth }\end{array}$ & $\begin{array}{l}\text { penetration } \\
\text { resistance }\end{array}$ & $\begin{array}{c}\text { chlorophyll } \\
\text { content }\end{array}$ & $\begin{array}{l}\text { bulk } \\
\text { density }\end{array}$ & $\begin{array}{l}\text { median } \\
\text { grain size }\end{array}$ & $\begin{array}{l}\text { very fine } \\
\text { sediment }\end{array}$ \\
\hline Alitta succinea & 8.94 & -1.04 & $\begin{array}{l}-0.09 \\
* * *\end{array}$ & -0.31 & -0.04 & $0.13 *$ & $-0.02 *$ & -0.02 \\
\hline Aphelochaeta & 0.23 & -2.78 & 0.1 & $0.34 * *$ & $0 *$ & $3.33 * * *$ & -0.01 & 0.03 \\
\hline Corophium volutator & 7.89 & $0.32 *$ & 0.03 & -0.21 & $-0.05 * *$ & $4.7^{* * *}$ & $-0.01 * *$ & $-0.08 * * *$ \\
\hline Crangon crangon & 7.2 & -2.11 & -0.33 & -1.03 & -0.03 & $1.33 * *$ & 0.03 & 0.01 \\
\hline Cyathura carinata & 5.07 & 0.24 & -0.01 & 0.13 & 0 & $-1.28 *$ & $0.01 *$ & $0.05 * *$ \\
\hline Eteone.spp & 5.17 & $-0.51 * *$ & 0.07 & 0.11 & $-0.03 *$ & 0.94 & $-0.01 * * *$ & $-0.04 * *$ \\
\hline Hediste diversicolor & 5.35 & -0.07 & $0.1 * *$ & 0.14 & $0.02 *$ & $-2.81 * * *$ & 0.01 & 0.03 \\
\hline Heteromastus filiformis & 7.78 & -0.17 & $\begin{array}{l}0.11 \\
* * *\end{array}$ & 0.07 & 0.01 & 0.3 & 0 & -0.02 \\
\hline Limecola balthica & 4.97 & $-0.88 * *$ & 0.13 & -0.4 & -0.02 & $1.59^{* * *}$ & 0 & 0 \\
\hline Nemertea & 1.81 & -1.15 & 0.05 & 0.16 & -0.01 & $2.46 * * *$ & 0 & 0.01 \\
\hline Nereis & 2.15 & 0.46 & $0.08^{*}$ & -0.1 & 0.02 & 0.24 & 0.01 & 0.01 \\
\hline Oligochaeta & -11.86 & 1.75 & 0.26 & $0.24 *$ & 0.06 & $14.26^{* *}$ & -0.01 & -0.21 \\
\hline Peringia ulvae & 6.61 & -2.59 & -0.11 & -0.06 & $0.07^{* * *}$ & -1.44 & -0.01 & 0.04 \\
\hline Polydora cornuta & -0.47 & 1.76 & $0.06 *$ & 0.14 & 0.07 & $3 * *$ & $-0.02 *$ & -0.03 \\
\hline Pygospio elegans & 6.13 & -0.21 & 0.09 & 0.36 & $-0.02 * *$ & $1^{* *}$ & 0 & 0 \\
\hline Scrobicularia plana & 3.33 & 0.83 & -0.22 & 0.25 & $0.06^{*}$ & $-4.61 *$ & $-0.02 *$ & $0.2 * *$ \\
\hline Streblospio benedicti & -0.43 & 0.75 & $0.46 * *$ & 0.24 & -0.06 & 11.6 & -0.05 & $-0.54 * * *$ \\
\hline
\end{tabular}


Table 6. The coefficients for the multivariate generalized linear model of taxa biomass explained by sediment characteristics. Significant negative coefficients are highlighted in blue, significant positive coefficients are highlighted in red. The significance levels are: $0.1>*>0.05>* *>0.01>* * *$

\begin{tabular}{|c|c|c|c|c|c|c|c|c|}
\hline & (Intercept) & $\begin{array}{c}\text { elevatio } \\
n\end{array}$ & $\begin{array}{l}\text { mud } \\
\text { depth }\end{array}$ & $\begin{array}{l}\text { penetration } \\
\text { resistance }\end{array}$ & $\begin{array}{c}\text { chlorophyll } \\
\text { content }\end{array}$ & $\begin{array}{l}\text { bulk } \\
\text { density }\end{array}$ & $\begin{array}{l}\text { median } \\
\text { grain size }\end{array}$ & $\begin{array}{l}\text { very fine } \\
\text { sediment }\end{array}$ \\
\hline Alitta succinea & 10.46 & -2.14 & $-0.19 * *$ & -0.25 & -0.01 & -0.12 & -0.02 & 0.01 \\
\hline Aphelochaeta & -0.27 & -2.84 & $0.19 *$ & 0.31 & $-0.02 *$ & $1.73 * *$ & -0.01 & 0.04 \\
\hline Corophium volutator & 8.26 & $0.12 * *$ & -0.03 & -0.38 & $-0.05 * *$ & $4.03 * * *$ & $-0.01 * * *$ & -0.08 \\
\hline Crangon crangon & 4.83 & -3.4 & -0.3 & -0.7 & 0 & $1.27^{*}$ & $0.04 *$ & 0.05 \\
\hline Cyathura carinata & 4.72 & 0 & -0.02 & 0.05 & 0 & -0.94 & 0.01 & $0.04 * *$ \\
\hline Eteone.spp & 2.25 & -0.43 & $0.33 *$ & 0.65 & 0 & $-3.08 * *$ & 0 & 0.08 \\
\hline Hediste diversicolor & 8.2 & 0.03 & $0.05 *$ & 0.06 & $0.03 * *$ & $-3.15 * * *$ & 0.01 & 0.01 \\
\hline Heteromastus filiformis & 7.64 & -0.16 & $0.13^{* * *}$ & 0.01 & 0.01 & -0.54 & 0.01 & -0.01 \\
\hline Limecola balthica & 7.09 & 0.23 & 0.03 & -0.09 & 0 & $-0.82 *$ & 0.01 & -0.02 \\
\hline Nemertea & 2.88 & -0.58 & 0.05 & -0.21 & -0.05 & $4.87^{* * *}$ & 0.01 & -0.09 \\
\hline Nereis & -1.3 & -1.69 & $0.18^{*}$ & 0.23 & 0.06 & -1.09 & $0.03 * *$ & 0.06 \\
\hline Oligochaeta & -9.9 & 1.42 & 0.04 & $-0.81 *$ & 0.05 & $9.17^{* * *}$ & -0.02 & -0.02 \\
\hline Peringia ulvae & 6.58 & -3.29 & -0.05 & -0.09 & $0.07 * *$ & $-2.25 *$ & -0.01 & 0.05 \\
\hline Polydora cornuta & -1.21 & 1.81 & -0.01 & 0.03 & 0.06 & $2.25 *$ & $-0.02 *$ & -0.01 \\
\hline Pygospio elegans & 2.84 & -0.21 & 0.09 & 0.33 & $-0.01 *$ & $1.23 * * *$ & 0 & 0 \\
\hline Scrobicularia plana & 15.09 & 3.69 & -0.32 & $-1.23 *$ & -0.11 & $-7.66 *$ & -0.05 & 0.22 \\
\hline Streblospio benedicti & -0.68 & 0.36 & $0.28 * *$ & 0.11 & -0.03 & 6.34 & $-0.02 *$ & $-0.35 * * *$ \\
\hline
\end{tabular}

Table 7. The coefficients for the multivariate generalized linear model of taxa abundance explained by point, year, season, and an interaction between year and season. Both point and season were treated as factors, and while the coefficient for season is for spring, we did not include all the coefficients for the points as these were largely not significant. Significant negative coefficients are highlighted in blue, significant positive coefficients are highlighted in red. The significance levels are: $0.1>*>0.05$ $>* *>0.01>* * *$

\begin{tabular}{|c|c|c|c|c|c|}
\hline & \\
\hline & (Intercept) & point & year & $\begin{array}{l}\text { season } \\
\text { (Spring) }\end{array}$ & $\begin{array}{l}\text { Interaction } \\
\text { between year } \\
\text { and Spring }\end{array}$ \\
\hline Alitta succinea & -72.95 & 3.91 & $0.04 * * *$ & $-2374.36 * *$ & $1.18^{* * *}$ \\
\hline Aphelochaeta & 1396.02 & $-1.52 *$ & $-0.69 * * *$ & -4.76 & 0.00 \\
\hline Corophium volutator & 2278.40 & 0.27 & $-1.13^{* * *}$ & $788.1^{* * *}$ & -0.39 \\
\hline Crangon crangon & 1565.67 & -2.23 & -0.78 & $-143.36 * * *$ & 0.07 \\
\hline Cyathura carinata & -2957.62 & 0.79 & $1.47 * * *$ & $-1808.3^{* * *}$ & $0.9 *$ \\
\hline Eteone.spp & 238.94 & 0.81 & -0.12 & -1257.05 & 0.62 \\
\hline Hediste diversicolor & -3825.97 & -2.54 & $1.9^{* * *}$ & $-1907.69 * *$ & 0.95 \\
\hline Heteromastus filiformis & -112.75 & 0.25 & 0.06 & $-6541.78 * * *$ & $3.24 * * *$ \\
\hline Limecola balthica & 671.19 & -0.86 & $-0.33 * * *$ & $2761.05 * * *$ & $-1.37 * * *$ \\
\hline Nemertea & 755.69 & -0.30 & $-0.37 * * *$ & 2551.04 & $-1.26^{* *}$ \\
\hline Nereis & -2777.95 & -3.23 & $1.38 * *$ & $7109.49 *$ & -3.53 \\
\hline Oligochaeta & 7335.16 & $-2.33 * *$ & $-3.64 * * *$ & 6258.61 & $-3.1 *$ \\
\hline Peringia ulvae & -2453.79 & 0.03 & $1.22 * * *$ & $-7346.24 * * *$ & $3.64^{*}$ \\
\hline Polydora cornuta & 1488.49 & 2.20 & $-0.74 * * *$ & $-1354.75 *$ & 0.67 \\
\hline Pygospio elegans & -1042.42 & $-1.32 *$ & 0.52 & $2324.41 * * *$ & $-1.15 * * *$ \\
\hline Scrobicularia plana & -7900.38 & -2.00 & $3.92 * * *$ & $2526.09 *$ & -1.25 \\
\hline Streblospio benedicti & 8712.01 & 22.02 & $-4.33 * * *$ & -9578.15 & 4.75 \\
\hline
\end{tabular}




\subsection{Birds usage of Perkpolder}

During low tide 16 species of waders (including Common shelduck, Tadorna tadorna) and 18 other species of water birds were recorded foraging in the managed realignment area during low tide (Figure 14). In total more than a 1000 Black-headed gulls (Chroicocephalus ridibundus), Common shelducks (Tadorna tadorna) and Mallards (Anas platyrhynchos) were recorded foraging in the area over a oneyear period (Table 8). Waders like Eurasian curlew (Numenius arquata) and Eurasian oystercatcher (Haematopus ostralegus), and the Common shelduck (Tadorna tadorna) are foraging during low tide in the intertidal zone, while the creeks are used by ducks such as Mallard (Anas platyrhynchos) and Wigeon (Mareca penelope). Little egrets (Egretta garzetta) look for small fish and crustaceans in the creeks. Figure 15 shows the diet of the different waders found within Perkpolder. The available food in the managed realignment area mainly consist of worms (green circle Figure 15). The presence of dunlins (Calidris alpina) corresponds with the presence of their preferred food source in the area.

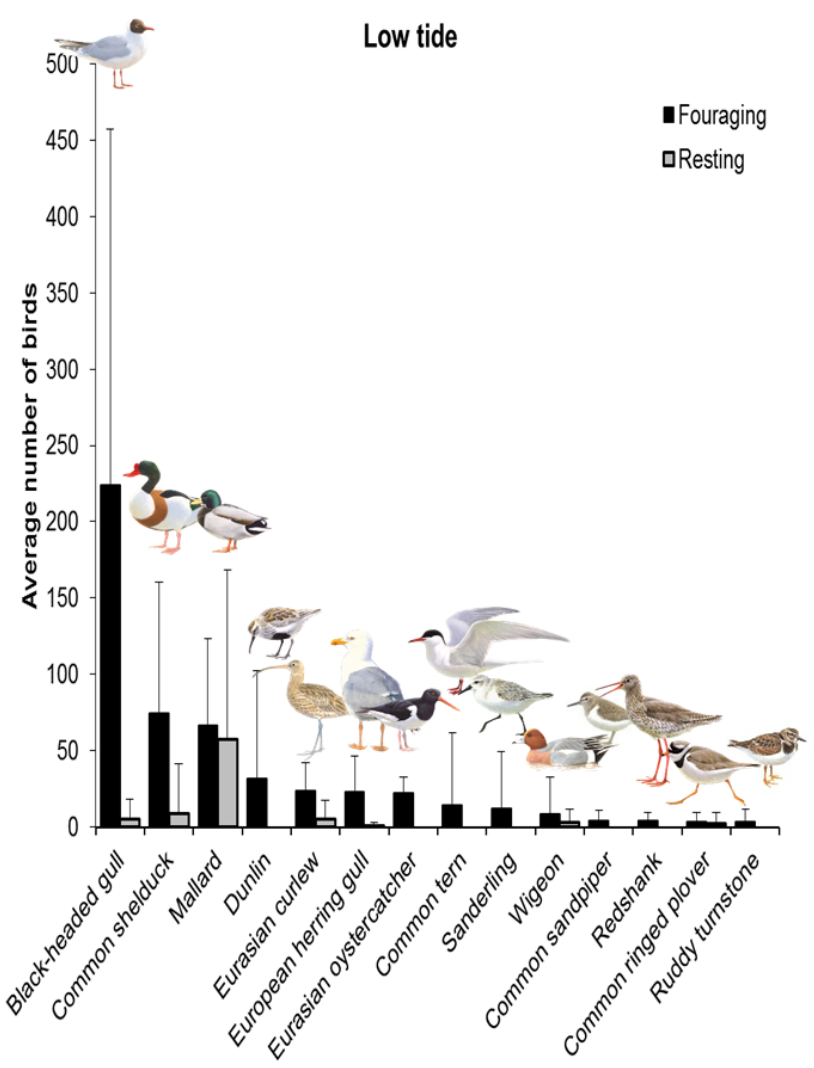

Figure 14. Average number of observed birds foraging and resting in the managed realignment area Perkpolder (75 ha) between September 2017 and September 2018. Pictures @ vogelbescherming.nl

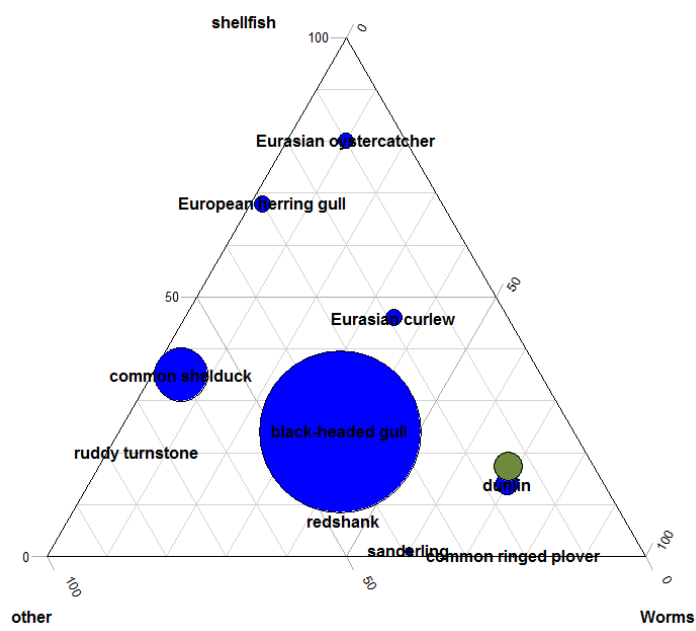

Figure 15. Diet and occurrence (ind. ha-2) of the top ten waders found in Perkpolder between September 2017 and September 2018. The location of the blue circle in the triangle indicate the diet composition. Distance to each corner represents relative importance of shellfish, worms or other macrobenthic 
organisms within their diet. Diet data was obtained from Leopold et al. 2004. The size of the circles indicates the relative density of species. The green circle indicate the benthic community composition and total biomass (size of the circles) in autumn 2018.

Dunlin, Mallard and Common shelduck, Bar-tailed godwit and Eurasian oystercatcher were the five most observed birds during high tide, using the dike around the managed realignment or the water as resting place (Figure 16). During each bird count all disturbances were counted (Figure 17). In September highest number of people (111) at the dikes surrounding Perkpolder were observed. Most of them were observed on the bike path at the west side of the area. On the east and south sides people are not permitted. Occasionally people do walk or bike there.

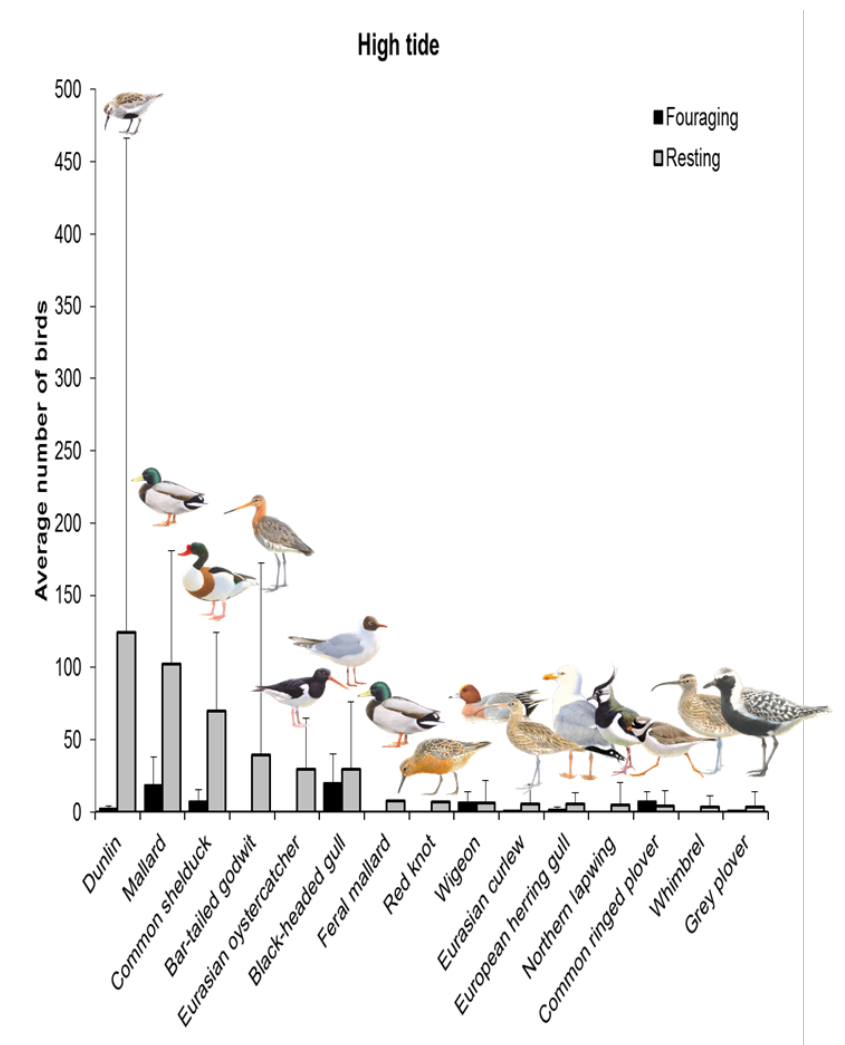

Figure 16. Average number of observed birds foraging and resting on the dikes surrounding the managed realignment area between September 2017 and September 2018. Pictures @ vogelbescherming.nl

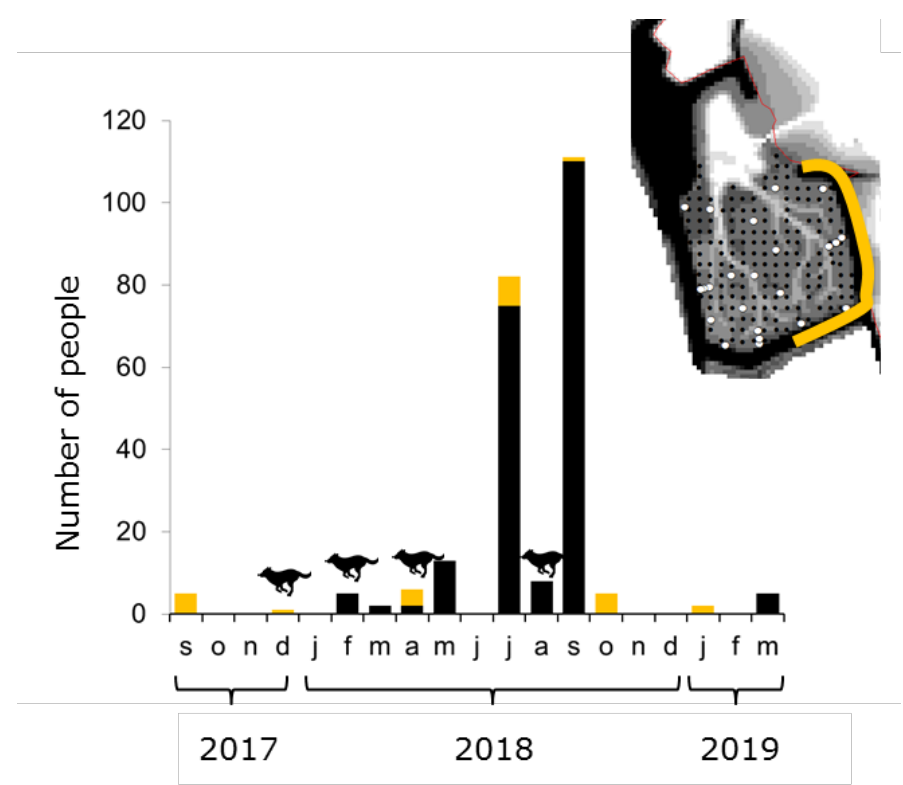

Figure 17. Number of people observed on the dikes surrounding Perkpolder. The west side is a bike path. On the east and south dike access is not permitted. For part of this stretch (yellow) it is known 
how many people visit do walk or bike here. At four occasions in time one dog was observed on the dike.

Table 8. Number of birds observed in the managed realignment Perkpolder (75 ha) during low tide and percentage showing foraging behaviour between September 2017 and September 2018.

\begin{tabular}{|c|c|c|c|c|c|c|c|c|c|}
\hline \multirow{2}{*}{ species } & \multicolumn{2}{|c|}{ spring } & \multicolumn{2}{|c|}{ summer } & \multicolumn{2}{|c|}{ autumn } & \multicolumn{2}{|c|}{ winter } & \multirow{2}{*}{ total } \\
\hline & $\mathrm{n}$ & $\%$ & $\mathrm{n}$ & $\%$ & $\mathrm{n}$ & $\%$ & $\mathrm{n}$ & $\%$ & \\
\hline Black-headed gull & 345 & 87 & 573 & 100 & 902 & 98 & 154 & 100 & 1974 \\
\hline Mallard & 94 & 100 & 136 & 100 & 835 & 21 & 234 & 100 & 1299 \\
\hline Comm on shelduck adult & 209 & 100 & 134 & 100 & 589 & 80 & 82 & 100 & 1014 \\
\hline Eurasian curlew & 71 & 18 & 25 & 100 & 76 & 100 & 104 & 88 & 276 \\
\hline European herring gull & 34 & 100 & 38 & 100 & 115 & 97 & 12 & 100 & 199 \\
\hline Eurasian oystercatcher & 55 & 100 & 37 & 100 & 23 & 100 & 73 & 100 & 188 \\
\hline Common tern & 154 & 100 & 6 & 100 & 0 & & 0 & & 160 \\
\hline Dunlin & 60 & 100 & 0 & & 68 & 100 & 0 & & 128 \\
\hline Wigeon & 0 & & 0 & & 3 & 100 & 114 & 91 & 117 \\
\hline Redshank & 9 & 100 & 2 & 100 & 22 & 100 & 8 & 100 & 41 \\
\hline Comm on shelduck juvenile & 0 & & 37 & 100 & 0 & & 0 & & 37 \\
\hline Comm on sandpiper & 0 & & 0 & & 37 & 100 & 0 & & 37 \\
\hline Ruddy turnstone & 34 & 100 & 0 & & 0 & & 0 & & 34 \\
\hline Sanderling & 0 & & 0 & & 22 & 100 & 5 & 100 & 27 \\
\hline Comm on ringed plover & 0 & & 0 & & 4 & 100 & 18 & 100 & 22 \\
\hline Great corm orant & 7 & 71 & 2 & 0 & 9 & 56 & 3 & 100 & 21 \\
\hline Grey plover & 15 & 100 & 0 & & 3 & 100 & 2 & 100 & 20 \\
\hline Bar-tailed godwit & 18 & 100 & 0 & & 1 & 0 & 0 & & 19 \\
\hline Comm on greenshank & 8 & 100 & 4 & 100 & 4 & 0 & 0 & & 16 \\
\hline Greylag goose & 0 & & 0 & & 14 & 0 & 0 & & 14 \\
\hline Lapwing & 0 & & 9 & 100 & 0 & & 0 & & 9 \\
\hline Little egret & 0 & & 0 & & 4 & 100 & 5 & 100 & 9 \\
\hline Feral Mallard & & & & & 8 & 0 & & & 8 \\
\hline Eurasian teal & 6 & 0 & 0 & & 2 & 100 & 0 & & 8 \\
\hline Great crested grebe & 2 & 100 & 2 & 100 & 0 & & 1 & 100 & 5 \\
\hline Eurasian spoonbill & 2 & 100 & 3 & 100 & 0 & & 0 & & 5 \\
\hline Whimbrel & 2 & 100 & 1 & 100 & 0 & & 0 & & 3 \\
\hline Great black-backed gull & 0 & & 0 & & 2 & 100 & 0 & & 2 \\
\hline Eurasian Pied avocet & 2 & 100 & 0 & & 0 & & 0 & & 2 \\
\hline Mediterranean gull & 2 & 100 & 0 & & 0 & & 0 & & 2 \\
\hline Grey heron & 0 & & 0 & & 1 & 100 & 0 & & 1 \\
\hline Red-breasted merganser & 1 & 100 & 0 & & 0 & & 0 & & 1 \\
\hline Spotted redshank & 0 & & 0 & & 1 & 0 & 0 & & 1 \\
\hline
\end{tabular}




\section{Discussion}

The inflow of water within the managed realignment area Perkpolder gave rise to morphological changes. Due to sediment import the resulting intertidal habitat is accretion over time. This enlarges the buffering function for flood protection as higher elevated intertidal habitat absorb and attenuate more wave energy. The fresh deposited layer of estuarine sediment also facilitated fast establishment and succession of the benthic macrofauna community. Initial colonisation of the realignment site by intertidal benthic macroinfauna was rapid with 19 species recorded during the first sampling, four months after the sea defences were breached in June 2015. This fast establishment can be related to both the planktonic stage of juveniles and the mobility of adults (Atkinson et al., 2001). Evans et al. (1999) showed for the Teesmouth managed realignment in the Tees estuary (UK), that establishment was slower when sediment was more compact. Here compaction was caused by earth moving equipment during the creation of the contours of the intertidal area. Increases in average abundance co-occurred with increase of depth of the mud layer on top of the former farmland in autumn 2016 and autumn 2018. Between autumn 2016 and spring 2018 the mud layer reduced in depth and penetration resistance increased indicating consolidation of the deposited sediment layer. During this period a decline in abundance was observed. Correspondingly at Tollesbury, in an estuary northwest of London, UK, Garbutt et al (2006) observed that invertebrate colonisation only occurred in newly accreted sediments within the realignment site.

The pioneering benthic community inside the managed realignment was structurally different from the estuarine area outside the managed realignment. The mud shrimp Corophium volutator was among the early colonizers. After three years of tidal inundation the benthic community of the realignment site is still in development and differs from that found on nearby tidal flats. Based on the current development in the direction of the community found on nearby tidal flats it can be expected that a stable community is reached within years rather than decades.

With the colonization of the benthic macrofauna into the Perkpolder area, also estuarine birds uses the area as foraging ground. Establishment of high numbers of $C$. volutator within four months after the breach contributes to the quality of this newly developing tidal area as foraging ground for birds as $C$. volutator is the main food of several small shorebird species. The most important food of large shorebirds, the ragworm Hediste diversicolor, appear in spring 2016 in low numbers, but did not become abundant until autumn 2018. Waders like Eurasian curlew (Numenius arquata) and Eurasian oystercatcher (Haematopus ostralegus), and the Common shelduck (Tadorna tadorna) are foraging during low tide in the intertidal zone, while the creeks are used by ducks such as Mallard (Anas platyrhynchos) and Wigeon (Mareca penelope). Little egrets (Egretta garzetta) look for small fish and crustaceans in the creeks. The number of birds observed within the managed realignment area could not be compared to nearby tidal flats, as low water bird counts were not available. Due to this, the relative importance of this area for bird cannot be quantified. Recently the Ministry of Transport, Public Works and Water Management started a new programme in which birds will be counted during low tide on several intertidal areas in the Westerschelde during the coming three years. This data could help obtain insight in the relative importance of an area as foraging area for birds.

For future coastal management it is important to understand how newly flooded coastal areas will develop. Our study shows that the managed realignment area Perkpolder was transformed into a biologically active intertidal area within a short time frame. The benthic community develops in the direction of a community found on nearby tidal flats. Birds uses the area as foraging ground. High numbers of people on the surrounding dikes indicate that the area also has a recreational value. Insights in the rate of development could help predict how future managed realignment areas such as HedwigeProsper will develop over time. 


\section{Conclusion}

For future coastal management it is important to understand how newly flooded coastal areas will develop. The development of the benthic community and the bird community within the managed realignment Perkpolder in the Scheldt estuary is encouraging. A former agricultural area has been transformed into a biologically active intertidal area within a short time frame. Within 3 years the benthic macro-infaunal community showed a development towards a community found on natural tidal mudflats and is expected to reach a stable community in years rather than decades. The area is frequently visited by birds which forage during low tide and rest on the surrounding dikes during high tide.

Recommendations:

To understand the relative importance of Perkpolder as foraging area for waders, comparison should be made with low water counts on nearby natural tidal flats. Low water counts are however rarely executed in the Scheldt estuary.

For this area, we recommend to perform another monitoring after 5 and 8 years, to see if the area has developed towards a fully natural intertidal area.

The uses of the area by fish is unknown. By catching the fish in the area, information can be obtained about the function of this area. A comparison between a newly created tidal area and natural tidal areas could provide insight in the expected development of this area for fish. 
This report is part of the Perkpolder monitoring project that was executed by the Centre of Expertise Delta Technology. This is a consortium formed by the University of Applied Sciences (Zeeland), Wageningen Marine Research, NIOZ and Deltares and financed by Rijkswaterstaat. This research was also partly financed by the Ministry of Public Affairs, within the framework of the Kennisbasis Programme System Earth Management (project KB-24-001-14). We would like to thank Natuurbeschermingsvereniging De Steltkluut for executing low and high water counts. 


\section{Quality Assurance}

Wageningen Marine Research utilises an ISO 9001:2015 certified quality management system. This certificate is valid until 15 December 2021. The organisation has been certified since 27 February 2001. The certification was issued by DNV GL.

Furthermore, the chemical laboratory at IJmuiden has NEN-EN-ISO/IEC 17025:2005 accreditation for test laboratories with number L097. This accreditation is valid until $1^{\text {th }}$ of April 2021 and was first issued on 27 March 1997. Accreditation was granted by the Council for Accreditation. The chemical laboratory at IJmuiden has thus demonstrated its ability to provide valid results according a technically competent manner and to work according to the ISO 17025 standard. The scope (L097) of de accredited analytical methods can be found at the website of the Council for Accreditation (www.rva.nl).

On the basis of this accreditation, the quality characteristic $Q$ is awarded to the results of those components which are incorporated in the scope, provided they comply with all quality requirements. The quality characteristic $\mathrm{Q}$ is stated in the tables with the results. If, the quality characteristic $\mathrm{Q}$ is not mentioned, the reason why is explained.

The quality of the test methods is ensured in various ways. The accuracy of the analysis is regularly assessed by participation in inter-laboratory performance studies including those organized by QUASIMEME. If no inter-laboratory study is available, a second-level control is performed. In addition, a first-level control is performed for each series of measurements.

In addition to the line controls the following general quality controls are carried out:

- Blank research.

- Recovery.

- Internal standard

- Injection standard.

- Sensitivity.

The above controls are described in Wageningen Marine Research working instruction ISW 2.10.2.105. If desired, information regarding the performance characteristics of the analytical methods is available at the chemical laboratory at IJmuiden.

If the quality cannot be guaranteed, appropriate measures are taken. 


\section{References}

Aminot, A. \& Rey F. (2000). Standard procedure for the determination of chlorophyll a by spectroscopic methods. International Council for the Exploration of the Sea. ISSN 0903-2606.

Atkinson, P.W., S. Crooks, A. Grant, M.M. Rehfish (2001). The success of creation and restoration schemes in producing intertidal habitat suitable for water birds. English Nature Research Report No. 425. English Nature, Peterborough.

Bouma, H., D.J. de Jong, F. Twisk en K. Wolfstein (2005): "Zoute wateren EcotopenStelsel (ZES.1): Voor het in kaart brengen van het potentiële voorkomen van levensgemeenschappen in zoute en brakken rijkswateren", RIKZ rapport 2005.024, Middelburg.

Craeymeersch, J., \& V. Escaravage (2014). Perceel Benthos. PMR Monitoring natuurcompensatie Voordelta. Eindrapport 1e fase 2009-2013 deel B. . In: T. Prins and G. van der Kolff. Delft D (ed) Deltares rapport $1200672-$ ZKS-0043.

Craft, C., J. Sacco (2003). Long-term succession of benthic infauna communities on constructed Spartina alterniflora marshes. Marine Ecology Progress Series 257: 45-58.

Esteves, L.S., 2014. Managed realignment: a viable long-term coastal management strategy? Springer Briefs in Environmental Science. Springer, New York, pp. 1-139. http://dx.doi.org/10.1007/978-94-017-9029-1.

Evans, P.R. R.M. Ward, M. Bone, M. Leakey (1999). Creation of themperate-climate intertidal mudflats: factors affecting colonization and use by benthic invertebrates and their bird predators. Marine Pollution Bulletin 37: 535-545.

Ferreira, S.M., Pardal, M.A., Lillebø, A.I., Cardoso, P.G., and Marques, J.C. (2004). Population dynamics of Cyathura carinata (Isopoda) in a eutrophic temperate estuary. Estuarine, Coastal and Shelf Science 61, 669-677.

Garbutt R.A., C.J. Reading, M. Wolters, A.J. Gray, P. Rothery (2006). Monitoring the development of intertidal habitats on former agricultural land after the managed realignment of coastal defences at Tollesbury, Essex, UK. Marine Pollution Bulletin 53: 155-164.

Giere, O. (2006). Ecology and Biology of Marine Oligochaeta - an Inventory Rather than another Review. Hydrobiologia 564, 103-116.

Leopold, M. F., Smit, C. J., Goedhart, P. W., Winden, A. J. V., Turnhout, C. V. (2004). Langjarige trend in aantallen wadvogels, in relatie tot de kokkelvisserij en het gevoerde beleid in deze. Alterra.

Levin L.A., D. Talley, G. Thayer (1996). Succession of macrobenthos in a created salt marsh. Marine Ecology Progress Series 141: 67-82.

Marlin, 2016 BIOTIC - Biological Traits Information Catalogue. Marine Life Information Network. Plymouth: Marine Biological Association of the United Kingdom. [december 2018] Available from www.marlin.ac.uk/biotic

Moseman S.M., L.A. Levin, C. Currin, C. Forder (2004). Colonization, succession, and nutrition of macrobenthic assemblages in a restored wetland at Tijuana Estuary, California. Estuarine Coastal Shelf Science 60: 755-770.

Mazik, K., J.E. Smith, A. Leighton, M. Elliott (2007). Physical and biological development of a newly breached managed realignment site, Humber estuary, UK. Marine Pollution Bulletin 55: 564578.

Oksanen J, F.G. Blanchet, M. Friendly, R. Kindt, P. Legendre, D. McGlinn, P.R. Minchin, R.B. O'Hara, G.L. Simpson, P. Solymos, M.H.H. Stevens, E. Szoecs, H. Wagner (2018). Vegan: community ecology package. $\mathrm{R}$ package version 2.5-3

Queirós, A.M., Birchenough, S.N.R., Bremner, J., Godbold, J.A., Parker, R.E., Romero-Ramirez, A., Reiss, H., Solan, M., Somerfield, P.J.,

R core Team (2018). R: A language and environment for statistical computing. R Foundation for Statistical Computing, Vienna, Austria.

Soetaert, K. \& Herman, P. M. J. (1995). Estimating estuarine residence times in the Westerschelde (The Netherlands) using a box model with fixed dispersion coefficients. Hydrobiologia 311, 215-224.

Ysebaert, T., Fettweis, M., Meire, P., and Sas, M. (2005). Benthic variability in intertidal soft-sediments in the mesohaline part of the Schelde estuary. Hydrobiologia 540.

Wang, Y., Naumann, U., Eddelbuettel, D., D. Warton (2018). Mvabund: Statistical methods for analysing multivariate abundance data. $\mathrm{R}$ packages version 3.13.1 


\section{Justification}

Report: C043/19

Project Number: 4313100023

The scientific quality of this report has been peer reviewed by a colleague scientist and a member of the Management Team of Wageningen Marine Research

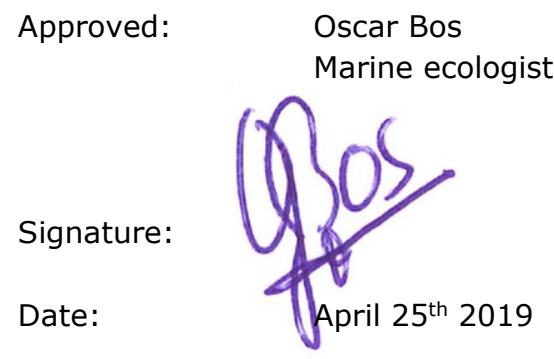

$\begin{array}{ll}\text { Approved: } & \text { Jakob Asjes } \\ & \text { Manager integration }\end{array}$

Signature:

Date:

April $25^{\text {th }} 2019$ 
Wageningen Marine Research

$T+31(0) 317480900$

E: marine-research@wur.n

www.wur.eu/marine-research

Visitors' address

- Ankerpark 271781 AG Den Helder

- Korringaweg 7, 4401 NT Yerseke

- Haringkade 1, 1976 CP IJmuiden
With knowledge, independent scientific research and advice, Wageningen Marine Research substantially contributes to more sustainable and more careful management, use and protection of natural riches in marine, coastal and freshwater areas.
Wageningen Marine Research is part of Wageningen University \& Research. Wageningen University \& Research is the collaboration between Wageningen University and the Wageningen Research Foundation and its mission is: 'To explore the potential for improving the quality of life' 